\title{
Ammonite Faunas of the Sarten Sandstone (Cretaceous), Luna County, New Mexico
}

\section{U.S. GEOLOGICAL SURVEY BULLETIN 1641-B}

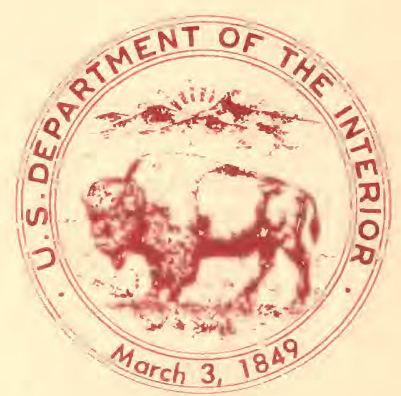





\section{Ammonite Faunas of the Sarten Sandstone (Cretaceous), Luna County, New Mexico}

By WILLIAM A. COBBAN

Three ammonite faunas of low diversity are described from rocks of late Albian to early

Cenomanian age

\section{Contributions to Paleontology}




\section{DEPARTMENT OF THE INTERIOR DONALD PAUL HODEL, Secretary}

U.S. GEOLOGICAL SURVEY Dallas L. Peck, Director

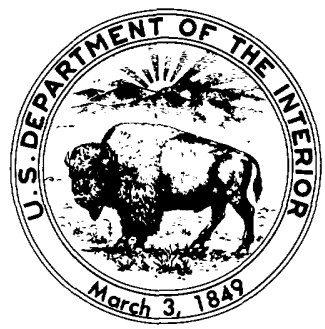

For sale by the

Books and Open-File Reports Section

U.S. Geological Survey

Federal Center

Box 25425

Denver, CO 80225

Library of Congress Cataloging in Publication Data

Cobban, William Aubrey, 1916-

Ammonite faunas of the Sarten sandstone (Cretaceous), Luna County, New Mexico.

(Contributions to paleontology) (U.S. Geological Survey Bulletin ; 1641-B)

Bibliography: $p$.

Includes index.

Supt. of Docs. No.: | 19.3:1641-B

1. Ammonoidea. 2. Paleontology-Cretaceous. 3. Paleontology-New Mexico-Luna County.

I. Title. II. Series. III. Series: U.S. Geological Survey bulletin ; 1641-B.

QE75.B9

[QE807.A5]

no. $1641-B$

$557.3 \mathrm{~s}$

$\left[564^{\prime} .53\right]$

86-600106 


\title{
CONTENTS
}

\author{
Abstract 1 \\ Introduction 1 \\ Localities of collections 2
}

Ammonite faunas of the Sarten Sandstone 2

Distribution of the ammonite faunas in New Mexico and Texas 3

Age of the Sarten Sandstone 4

Systematic descriptions $\mathbf{5}$

Family Pachydiscidae Spath, 19225

Genus Eopachydiscus Wright, $1955 \quad 5$

Eopachydiscus marcianus (Shumard) $\mathbf{5}$

Family Brancoceratidae Spath, 19346

Subfamily Mortoniceratinae Spath, 19256

Genus Mortoniceras Meek, $1876 \quad 6$

Mortoniceras equidistans (Cragin) 6

Mortoniceras aff. M. leonense (Conrad) 8

Mortoniceras sp. $\mathbf{8}$

Subgenus Drakeoceras Young, $1957 \quad 8$

Mortoniceras (Drakeoceras) sp. 9

Family Acanthoceratidae Hyatt, 19009

Genus Mantelliceras Hyatt, 19039

Mantelliceras sp. 9

Family Engonoceratidae Hyatt, 190010

Genus Engonoceras Neumayr and Uhlig, $1881 \quad 10$

Engonoceras belviderense (Cragin) $\mathbf{1 0}$

Engonoceras sp. $\mathbf{1 0}$

Family Turrilitidae Meek, $1876 \quad \mathbf{1 0}$

Genus Turrilites Lamarck, $1801 \quad \mathbf{1 0}$

Turrilites aff. $T$. costatus Lamarck 10

References cited $\mathbf{1 1}$

Index 15

\section{PLATES}

1. Eopachydiscus, Engonoceras, and Mortoniceras.

2. Eopachydiscus, Mortoniceras, and Turrilites.

3. Mortoniceras and Eopachydiscus.

4. Mantelliceras, Engonoceras, and Mortoniceras.

5. Mortoniceras.

\section{FIGURE}

1. Map showing outcrops of Sarten Sandstone and localities of ammonite collections 1 


\section{TABLES}

1. Localities at which ammonites were collected 2

2. Upper Albian-lower Cenomanian ammonite zonation in Texas 4

3. Upper Albian ammonite zonation in southern England $\mathbf{5}$

4. Upper Albian ammonite zonations proposed recently $\mathbf{5}$ 


\section{Ammonite Faunas of the Sarten Sandstone (Cretaceous), Luna County, New Mexico}

\section{By William A. Cobban}

\section{Abstract}

Three ammonite faunas of low diversity occur in the Sarten Sandstone of the Cooke Range, New Mexico. Mortoniceras equidistans (Cragin) and Eopachydiscus marcianus (Shumard), of middle late Albian age, characterize the oldest fauna, which is found a little below the middle of the formation. Mortoniceras (Drakeoceras) sp. and Engonoceras belviderense (Cragin) occur in the next younger Albian fauna, about in the middle of the Sarten. Fragments of a robust, sparsely ribbed Mantelliceras of early Cenomanian age and a single specimen of Turrilites aff. T. costatus Lamarck were found at the top of the Sarten.

The oldest fauna is also known from the Smeltertown Formation of Strain (1968) near El Paso, Texas. Farther east in Texas, this fauna is restricted to the Duck Creek Formation. The middle (Drakeoceras) fauna of the Sarten Sandstone is probably the age equivalent of some part of the Fort Worth Limestone of north and north-central Texas. Ammonites and the associated bivalves at the top of the Sarten suggest an age equivalent of the Buda Limestone of Texas.

\section{INTRODUCTION}

The Sarten Sandstone was named by Darton (1916, p. 19, 43) for outcrops on Sarten Ridge (now Rattlesnake Ridge) in the Cooke Range north of Deming, N. Mex. (fig. 1). From limy beds a little below the middle of the formation, Darton collected marine fossils which were determined as Early Cretaceous in age by T. W. Stanton (in Darton, 1916, p. 43). Two collections were made by Darton, one on Sarten Ridge and the other on Fluorite Ridge (fig. 1). These collections contained 12 species of bivalves and 3 species of gastropods, but no ammonites. Stanton (in Darton, 1916, p. 44) stated that the fossils "represent the forms of the Washita group of the Comanche series and show about the same faunal facies as that found in the marginal deposits of southern Kansas and near Tucumcari, N. Mex." The lists of fossils were published again by Darton (1917) and later repeated by Jicha $(1954$, p. 26). Nothing further has been written regarding the fauna of the Sarten Sandstone.

In recent years personnel of the U.S. Geological Survey and New Mexico Bureau of Mines and Mineral Resources have made collections of fossils from the Sar-

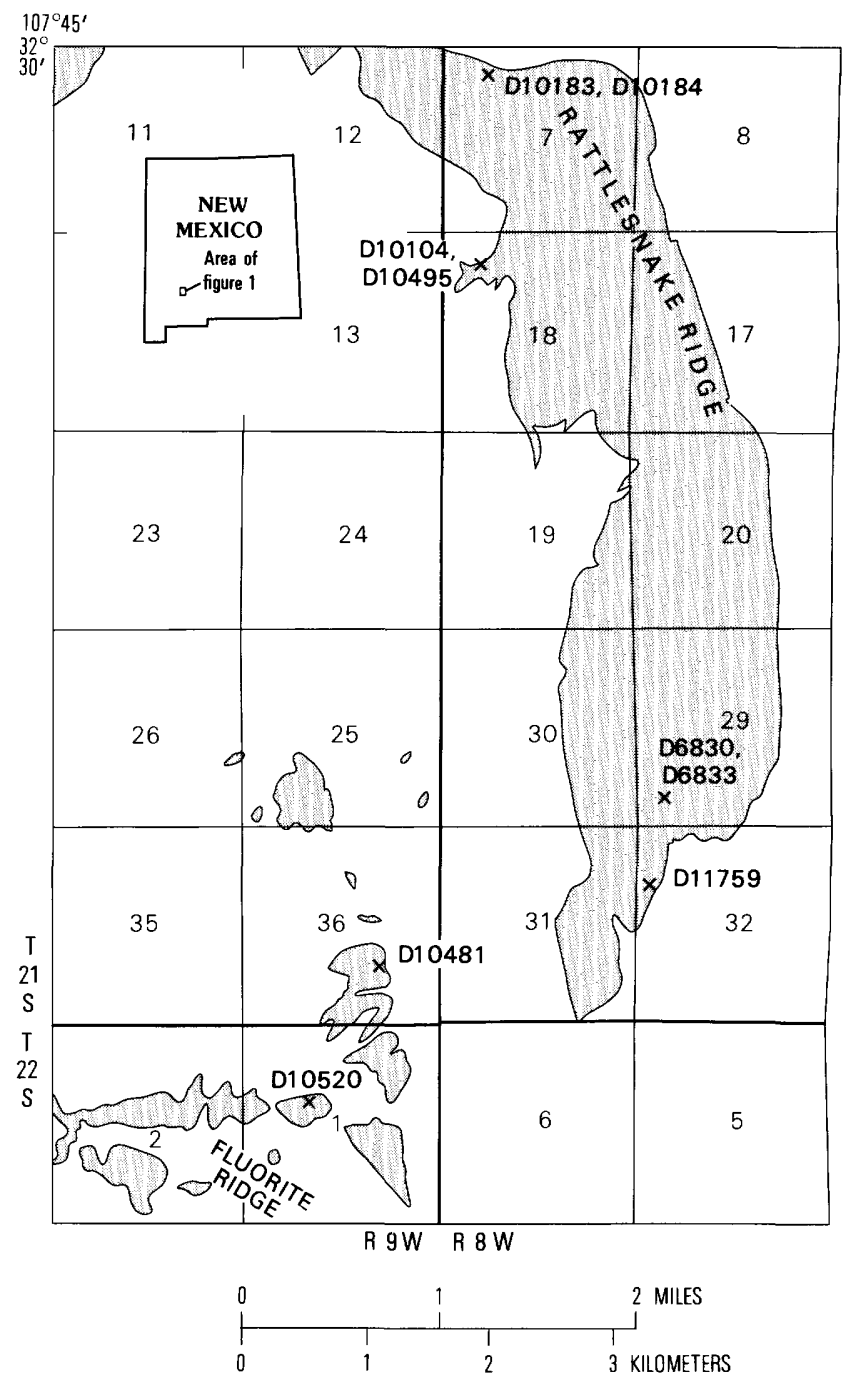

Figure 1. Map showing outcrops of Sarten Sandstone (patterned) and localities of ammonite collections. Sarten outcrops from Clemons (1982).

ten Sandstone in the Cooke Range. Some of these collections contain certain ammonites that permit a refined age assignment and correlation of the Sarten. Although most of the ammonites consist of fragments, representative specimens are described and illustrated in this report because of their importance in dating and correlating the Sarten Sandstone.

All specimens illustrated in this report are in the National Museum of Natural History in Washington, 
D.C., and have USNM catalog numbers. Plaster casts of some of the figured specimens are in the U.S. Geological Survey's Mesozoic invertebrate fossil collections at the Denver Federal Center, Denver, Colo., and at the New Mexico Bureau of Mines and Mineral Resources, Socorro, N. Mex. Robert E. Burkholder of the U.S. Geological Survey made the photographs. Thomas Hyatt of Deming, $\mathrm{N}$. Mex., kindly allowed access to the localities where collections were made. Dr. W. J. Kennedy, Oxford University, England, gave helpful advice concerning ammonites from the top of the Sarten Sandstone.

\section{LOCALITIES OF COLLECTIONS}

The ammonites described or recorded in this report came from nine localities. These localities are shown on figure 1 , and data concerning the localities, stratigraphic positions in the Sarten Sandstone, and collectors are given in table 1.

\section{AMMONITE FAUNAS OF THE SARTEN SANDSTONE}

Ammonites were collected from three levels in the Sarten Sandstone. The oldest and largest collection came from a limy unit below the middle of the formation, where fragments of ammonites occur as uncrushed internal molds of limestone. Some molds have oyster encrustations. Mortoniceras equidistans (Cragin) is the dominant species of mollusks in these limy beds. Other genera include Engonoceras sp. and Eopachydiscus, the latter represented by $E$. marcianus (Shumard).

Sandy beds about $24 \mathrm{~m}$ above the fossiliferous limy beds have septarian limestone concretions that contain occasional fragments of Mortoniceras and Engonoceras. The specimens of Mortoniceras are distorted and poorly preserved; because they are bituberculate, they are assignable to the subgenus Drakeoceras.

The uppermost meter of the Sarten consists of sandy nodular limestone that contains a few internal molds of fossil mollusks as well as fragments of shells of large Exogyra. Most of the fossils seem characteristic of the Buda Limestone of Texas and Mexico. Six of the seven specimens of ammonites collected represent a sparsely ribbed, robust Mantelliceras that has affinities with $M$. budaense Adkins (1931, p. 41, pl. 2, fig. 3; pl. 4, fig. 10). Adkins' holotype came from the top of the Buda Limestone near Austin, Texas. Mantelliceras budaense has been regarded as a questionable synonym of the English $M$. cantianum Spath $(1926$, p. 82$)$ by Matsumoto, Muramoto, and Takahashi $(1969$, p. 256) and as a more definite synonym by Kennedy (1971, p. 56), Young (1979, p. 21), and Mancini (1982, p. 253). Mantelliceras cantianum, however, seems more densely ribbed than $M$. budaense and has more discrete lower lateral tubercles.
Table 1. Localities at which ammonites were collected

\begin{tabular}{cc}
$\begin{array}{c}\text { U.S. Geological } \\
\text { Survey Mesozoic } \\
\text { locality }\end{array}$ & $\begin{array}{c}\text { Collector, year of collection, description of } \\
\text { locality, and stratigraphic position }\end{array}$ \\
\hline
\end{tabular}

D6830 E. R. Landis and W. A. Cobban, 1968; J. R. Wright and S. C. Hook, 1977; E. A. Merewether, S. C. Hook, and W. A. Cobban, 1978. SW1/4SW1/4 sec. 29, T. 21 S., R. 8 W. From very light gray weathering, hard, nodular limestone below middle of Sarten Sandstone.

D6833 E. R. Landis and W. A. Cobban, 1968. Same area as D6830. From gray- and brown-weathering septarian limestone concretions 73 feet $^{1}(22.3 \mathrm{~m})$ above D6830

D10104 E. R. Landis, S. C. Hook, and W. A. Cobban, 1976; J. R. Wright, D. E. Tabet, S. C. Hook, and W. A. Cobban, 1977; R. R. Cobban, S. C. Hook, and W. A. Cobban, 1980. NW1/4NW1/4 sec. 18, T. 21 S., R. 8 W. From sandy, nodular limestone at top of Sarten Sandstone.

D10183 Richard Naff and S. C. Hook, 1977. NE $1 / 4$ NW $1 / 4 N^{2} 1 / 4$ sec. 7, T. 21 S., R. $8 \mathrm{~W}$. From orange-weathering, sandy, nodular limestone in lower part of Sarten Sandstone.

D10184 Richard Naff, J. R. Wright, S. C. Hook, and W. A. Cobban, 1977. NW1/4NW1/4 sec. 7, T. 21 S., R. 8 W. From lightgray-weathering nodular limestone about 31 feet $(9.5 \mathrm{~m})$ above D10183 and same stratigraphic position as D6830.

D10481 E. A. Merewether, S. C. Hook, and W. A. Cobban, 1978. SE1/4NW1/4SE $1 / 4 \mathrm{sec}$. 36, T. 21 S., R. 9 W. From brownweathering limestone about stratigraphic position of D6833.

D10495 W. A. Cobban, 1978. NW1/4NW1/4 sec. 18, T. 21 S., R. 8 W. From sandy, nodular limestone at top of Sarten Sandstone.

D10520 S. C. Hook and W. A. Cobban, 1978. SE $1 / 4 \mathrm{NW}^{1 / 4}$ sec. 1, T.22 S., R. $9 \mathrm{~W}$. From light-gray nodular limestone at same stratigraphic position as D6830.

D11759 S. C. Hook, 1982. NW $1 / 4 \mathrm{SW}^{1 / 4} \mathrm{NW}^{1 / 4} \mathrm{sec}$. 32, T. 21 S., R. 8 W. From light-gray nodular limestone at same stratigraphic position as D6830

\footnotetext{
'Principal units of measurement in this report are metric. However, measurements originally made in inch-pound units are given in those units, followed by metric equivalents in parentheses.
}

The holotype of $M$. cantianum (Sharpe, 1856, pl. 18, figs. 1,2) has 33 ribs per whorl, whereas the holotype of $M$. budaense has 25 or 26 . In addition, $M$. cantianum 
is probably an older species than $M$. budaense. Kennedy $(1969,1970,1971)$ has recognized for the lower Cenomanian of England a zone of Mantelliceras mantelli (J. Sowerby), which is divisible into a lower Hypoturrilites carcitanensis (Matheron) assemblage, a medial Mantelliceras saxbii (Sharpe) assemblage, and an upper Mantelliceras gr. dixoni Spath assemblage. The lower assemblage contains $M$. cantianum and other species of Mantelliceras; the medial assembly contains occasional $M$. cantianum and other species; and the upper assemblage contains $M$. gr. dixoni, $M$. aff. souaillonense (Renz), M. lymense (Spath) and rare $M$. cf. mantelli as well as the first appearance of Turrilites costatus Lamarck and $T$. scheuchzerianus Bosc. Inasmuch as Turrilites aff. T. costatus was also found with Mantelliceras at the top of the Sarten, the age of these Sarten ammonites seems to be high in the early Cenomanian and probably equivalent to Kennedy's Mantelliceras gr. dixoni assemblage.

The Buda Limestone of Texas has not been zoned in detail, although four ammonite zones have been recognized in the lower Cenomanian part of the underlying Grayson Formation (Mancini, 1979). Young (1967a, p. 67-70) assigned the Buda to the zone of Budaiceras hyatti and noted that "the main diagnostic fossils of the Buda Limestone are of the ammonite genera Budaiceras and Faraudiella. The ammonites are so rare in the Buda that a zonation has not yet been possible. However, 99 percent of the ammonites from Hays, Travis, and Williamson Counties are from the lower member, and not over a half dozen specimens are known from the upper member" (Young, 1967b, p. 28). Budaiceras seems to occur mostly in the lower and middle parts of the Buda (Young, 1959, p. 79; Martin, 1967, p. 295), although Young (1979, p. 87-89) has noted it in the upper part at a few localities. Mantelliceras, however, seems to occur only in the upper part of the Buda (Adkins, 1931, p. 42; Reaser, 1970, p. 80 , fig. 11; Young, 1979, p. 88, 89).

The thin, sandy, nodular limestone unit at the top of the Sarten Sandstone in the Cooke Range is probably resting disconformably on a sandstone equivalent of the Anapra Sandstone (Strain, 1976, p. 81) of the El Paso area, where the Anapra is a 172-foot-thick, thick-bedded quartz sandstone that contains partings of siliceous shale. In the El Paso area, the Del Rio Clay separates the Anapra Sandstone from the Buda Limestone (Strain, 1976, p. 81). A disconformity at the base of the Buda equivalent in the Cooke Range is not surprising inasmuch as the Buda is known to rest disconformably on the Del Rio Clay or on older parts of the Washita Group at places in west-central and southwest Texas (for example, Brand and Deford, 1958, p. 385; Hazzard, 1959; DeFord and Haenggi, 1970, fig. 7; Moore, 1969, fig. 4; Rose, 1972, p. 23, 43, pl. 4 , text fig. 34). In part of south-central Texas, the upper part of the Buda rests disconformably on the lower part (Martin, 1967, p. 290, 298, figs. 2, 4).
The sandy nodular limestone bed at the top of the Sarten contains the following molluscan fauna (USGS Mesozoic locality D10104):

Syncyclonema sp.

Neithea (Neithea) texana (Roemer)

Lima shumardi Shuttuck

Exogyra clarki Shuttuck

E. whitneyi (Böse)

Pterotrigonia (Scabrotrigonia) sp.

Stearnsia sp.

Protocardia? sp.

Granocardium (Criocardium) budaense (Shuttuck)

Artica? compacta (White)

Homomya cf. H. budaensis Whitney

Turritella cf. $T$. semiatimgranulata Roemer

$T$. sp.

Tylostoma harrisi Whitney

Mantelliceras sp.

Turrilites aff. T. costatus Lamarck

Cymatoceras sp.

\section{DISTRIBUTION OF THE AMMONITE FAUNAS IN NEW MEXICO AND TEXAS}

The Eopachydiscus marcianus-Mortoniceras equidistans fauna in the lower part of the Sarten Sandstone can be readily correlated with similar faunas in southern New Mexico and in Trans-Pecos Texas. Farther east in Texas, Young (1967a) has shown the position of this zone (divided into a zone of $E$. brazosensis overlain by a zone of Pervinquieria equidistans) in regard to formations in south-central Texas, north-central Texas, north Texas, the High Plains, upper Concho and Llano River drainages, Fort Stockton quadrangle (Pecos County), and Cienega quadrangle (Presidio County). Perhaps the best known of the formations that contain this fauna is the Duck Creek Formation of north-central and north Texas. Eopachydiscus marcianus occurs abundantly in the lower part of this formation. Mortoniceras equidistans occurs with E. marcianus, but ranges higher than it.

Böse (1910, p. 16-30) divided the Cretaceous rocks into 11 lithologic units, numbered from the base upward, on the Sierra de Cristo Rey uplift, which lies astride the international boundary between the United States and Mexico just west of El Paso, Texas. Strain $(1968 ; 1976)$ gave new formal names to five of these units and applied names established elsewhere to four of the other units. Böse's unit number 4 (Capas con Schloenbachia nodosa, n. sp.), named Smeltertown Formation by Strain, contains Eopachydiscus marcianus and Mortoniceras equidistans (Böse's Schloenbachia trinodosa), of early-middle Sarten age. Böse did not record Eopachydiscus, but specimens have been found in the Smeltertown Formation at the type locality of the Smeltertown (USGS Mesozoic locality D10474). 
In Trans-Pecos Texas, the $E$. marcianus $-M$. equidistans fauna has been recorded from the Fort Stockton and Kent areas and from the Eagle Mountains farther southwest. The Fort Stockton area in Pecos County, about 200 miles $(322 \mathrm{~km})$ east-southeast of $\mathrm{El}$ Paso, has yielded many ammonites from rocks assigned to the Duck Creek Formation by Adkins (1927, p. 44). Eopachydiscus marcianus is represented by ammonites identified by Adkins as Desmoceras brazoense and $D$. laevicaniculatus, and Mortoniceras equidistans is represented by ammonites identified as Pervinquieria equidistans, $P$. kiliani, and $P$. whitei.

In the Kent area, about 140 miles $(225 \mathrm{~km})$ eastsoutheast of El Paso, Brand and DeFord (1958, p. 381) recorded $E$. marcianus (as $E$. brazoense and $E$. laevicaniculum) from the lower part of their Levinson Member of the Boracho Limestone, and $M$. equidistans (as Pervinquieria equidistans) slightly higher.

The Eagle Mountain area southwest of Kent and about 100 miles $(160 \mathrm{~km})$ southeast of El Paso has also yielded $E$. marcianus and $M$. equidistans. Underwood (1963, p. 9, 10) recorded $E$. marcianus (as $E$. cf. $E$. brazoense) and $M$. equidistans (as Pervinquieria equidistans) from the lower part of the Espy Formation of Huffington (1943, p. 1005).

In addition to the Cooke Range and El Paso area, the $E$. marcianus $-M$. equidistans fauna has been found in the Tucumcari area in the northeast part of New Mexico. Stanton (1928, p. 407) recorded Pervinquieria trinodosa [ $M$. equidistans] from beds now assigned to the Mesa Rica Sandstone in the Tucumcari area. Undescribed USGS collections made later from the Mesa Rica Sandstone in this area include excellent examples of $E$. marcianus and $M$. equidistans.

\section{AGE OF THE SARTEN SANDSTONE}

The Washita Group of Texas, to which Stanton (in Darton, 1916, p. 44) equated the Sarten Sandstone, includes upper Albian and lower Cenomanian rocks. The ages and correlations of the ammonite faunas of the Sarten can be determined best by comparing them to the better known ammonite faunas of Texas, as well as to those of the Anglo-Paris basin.

Young (1972, p. 7) established a sequence of seven ammonite zones for upper Albian rocks of Texas based on species of Manuaniceras, Adkinsites, Eopachydiscus, Pervinquieria, Drakeoceras, and Mortoniceras. Above this sequence, Young and Powell (1976, fig. 2) recognized five zones of lower Cenomanian ammonites based on species of Plesioturrilites, Graysonites, Budaiceras, and Forbesiceras. The Texas zonation of these authors is shown in table 2 .

Spath $(1923$, p. $73 ; 1926 ; 1942$, p. 671-673) proposed for the upper Albian of southern England two ammonite zones and six subzones based on species of Mor- toniceras, Stoliczkaia, Hysteroceras, Callihoplites, and Arrhaphoceras (table 3). Problems concerning Spath's zonation have been summarized by Cooper and Kennedy (1979, p. 298, 299), who adopted some suggestions for changes advocated by Owen (1975) and Breistroffer (1940; 1947). Cooper and Kennedy's zonation is shown in table 4 together with a later proposal by Amedro (1980, p. 239-244).

Table 2. Upper Albian-lower Cenomanian ammonite zonation in Texas

\begin{tabular}{|c|c|}
\hline Substage & Zone \\
\hline \multirow{5}{*}{ Lower Cenomanian } & Forbesiceras brundrettei (Young) \\
\hline & Budaiceras hyatti (Shattuck) \\
\hline & Graysonites lozoi Young \\
\hline & Graysonites adkinsi Young \\
\hline & Plesioturrilites brazosensis (Roemer) \\
\hline \multirow{7}{*}{ Upper Albian } & Drakeoceras drakei Young \\
\hline & Mortoniceras wintoni (Adkins) \\
\hline & Drakeoceras lasswitzi Young \\
\hline & Pervinquieria equidistans (Cragin) \\
\hline & Eopachydiscus brazosensis (Shumard) \\
\hline & Adkinsites bravoensis (Böse) \\
\hline & Manuaniceras powelli Young \\
\hline
\end{tabular}

Kennedy (1969, table 1) recognized for the early Cenomanian of southern England a Mantelliceras mantelli Zone with three assemblages, which from oldest to youngest include the Hypoturrilites carcitanensis assemblage, the Mantelliceras saxbii assemblage, and Mantelliceras gr. dixoni assemblage. These assemblages were not considered as subzones because the faunas were mostly at discrete stratigraphic positions separated by largely unfossiliferous beds.

The ammonite fauna from below the middle of the Sarten Sandstone includes Eopachydiscus marcianus and Mortoniceras equidistans. Inasmuch as E. brazoensis (Shumard, 1860) is a synonym of $E$. marcianus (Shumard, 1854), the fauna embraces the Texas middle upper Albian zones of E. brazoensis and Pervinquieria [Mortoniceras] equidistans of Young (1972, p. 7). Eopachydiscus marcianus has not been recorded from Europe, but M. kiliani (Lasswitz, 1904), a synonym of M. equidistans (Cragin, 1893), has been figured by Spath (1932, p. 408 , pl. 38 , figs. 1, 2; pl. 42, fig. 1; pl. 47, fig. 1) from his $M$. aequatoriale and Arrhaphoceras substuderi subzones of the upper Albian. 
Table 3. Upper Albian ammonite zonation in southern England

\begin{tabular}{c|l|l}
\hline \multirow{2}{*}{ Substage } & \multicolumn{1}{|c}{ Zone } & \multicolumn{1}{c}{ Subzone } \\
\hline \multirow{4}{*}{ Upper Albian } & \multirow{2}{*}{\begin{tabular}{l} 
Stoliczkaia dispar (d'Orbigny) \\
\cline { 2 - 3 }
\end{tabular}} & $\begin{array}{c}\text { Stoliczkaia dispar (d'Orbigny) and } \\
\text { Mortoniceras perinflatum (Spath) }\end{array}$ \\
\cline { 3 - 4 } & \multirow{2}{*}{ Mortoniceras inflatum (J. Sowerby) } & Arrhaphoceras substuderi Spath \\
\cline { 3 - 4 } & & Callihoplites auritus (J. Sowerby) \\
\cline { 3 - 4 } & & Hysteroceras varicosum (J. de C. Sowerby) \\
\cline { 3 - 4 } & & Hysteroceras orbignyi (Spath)
\end{tabular}

Table 4. Upper Albian ammonite zonations proposed recently

\begin{tabular}{|c|c|c|}
\hline \multicolumn{2}{|c|}{ Cooper and Kennedy (1979) } & \multirow{2}{*}{$\begin{array}{c}\text { Amédro (1980) } \\
\text { Assemblage-zone }\end{array}$} \\
\hline Zone & Subzone & \\
\hline \multirow{2}{*}{ Stoliczkaia dispar } & Mortoniceras (Durnovarites) perinflatum & Pervinquieria perinflata \\
\hline & Stoliczkaia (Faraudiella) blancheti & Pervinquieria fallax \\
\hline \multirow{3}{*}{ Mortoniceras inflatum } & Callihoplites auritus & Pervinquieria inflata \\
\hline & Hysteroceras varicosum & \multirow{2}{*}{ Pervinquieria pricei } \\
\hline & Hysteroceras orbignyi & \\
\hline
\end{tabular}

The poorly preserved Mortoniceras (Drakeoceras) fragments higher in the Sarten cannot be placed in any specific zone of the Texas late Albian sequence of Drakeoceras. Inasmuch as the fragments were collected not far above the beds containing $M$. equidistans, they may lie in Young's Drakeoceras lasswitzi Zone, which in north and north-central Texas includes the upper part of the Duck Creek Formation and the overlying Fort Worth Limestone and Weno Formation.

As noted earlier, the fauna at the top of the Sarten is of early Cenomanian age, about the age of the Buda Limestone.

\section{SYSTEMATIC DESCRIPTIONS}

\section{Family PACHYDISCIDAE Spath, 1922}

\section{Genus EOPACHYDISCUS Wright, 1955}

Type species.-Pachydiscus laevicaniculatus Lasswitz, 1904.

This genus includes large, compressed to inflated, fairly involute ammonites that have rounded flanks and a venter with constrictions and sparse thick ribs. Suture is characterized by a trifid lateral lobe (L) and numerous auxiliaries, all minutely frilled. The genus is mainly of late Albian age.

\section{Eopachydiscus marcianus (Shumard)}

Plate 1, figures 1-6; plate 2, figure 1; plate 3, figure 11

1854. Ammonites marcianus Shumard, p. 183, pl. 4, fig. 5 .

1860. Ammonites brazoensis Shumard, p. 594.

1893. Pachydiscus brazoensis (Shumard). Cragin, p. 236, pl. 44, fig. 3.

1894a. Pachydiscus marcianus (Shumard). Cragin, p. 54 (footnote).

1904. Pachydiscus laevicaniculatus F. Roemer manuscript. Lasswitz, p. 236, pl. 15, fig. 2; text figs. 8, 9.

1919 [1920]. Desmoceras brazoense (Shumard). Adkins and Winton, p. 35, pl. 2, figs. 1, 2.

1919 [1920]. Desmoceras sp. A. Adkins and Winton, p. 35, pl. 2, fig. 3.

1923. Pachydiscus? sp. Reeside, p. 205, pl. 49, fig. 1. 
1925. Desmoceras brazoense (Shumard). Bullard, pl. 20, figs. $1,2$.

1925. Desmoceras brazoense (Shumard). Winton, pl. 4, fig. 1.

1926. Desmoceras brazoense (Shumard). Bullard, pl. 16, fig. 1.

1927. Desmoceras brazoense (Shumard). Adkins, pl. 6, fig. 2.

1927. Desmoceras laevicaniculatum (Roemer). Adkins, pl. 6, fig. 1 .

1927. Desmoceras brazoense (Shumard). Bybee and Bullard, pl. 4 , fig. 1.

1928. Desmoceras? brazoense (Shumard). Adkins, p. 220, pl. 9, fig. 2.

1928. Desmoceras? laevicaniculatum (Roemer). Adkins, p. 220, pl. 9, fig. 1.

1928. Desmoceras? marcianum (Shumard). Adkins, p. 221.

1955. Eopachydiscus laevicaniculatus (Lasswitz, ex Roemer manuscript). Wright, p. 570.

1955. Eopachydiscus brazoensis (Shumard). Wright, p. 571.

1955. Eopachydiscus marcianus (Shumard). Wright, p. 571.

1957b. Eopachydiscus laevicaniculatus (Lasswitz). Wright, p. L377, fig. 493.

1960. Eopachydiscus brazoense (Shumard). Perkins, pl. 10, fig. 1.

The holotype of Ammonites marcianus Shumard (1854), which was never illustrated, may be lost. This specimen was a small, poorly preserved juvenile. Lasswitz (1904, pl. 15, fig. 2; text figs. 8, 9) was the first person to illustrate a good specimen. His drawings show a slender phragmocone about $130 \mathrm{~mm}$ in diameter with an umbilical ratio of 0.21 . Whorl section is oval with the greatest width at the lower part of the flank. The venter is narrowly rounded. A very narrowly rounded shoulder sharply defines the umbilicus. Six prorsiradiate to rectiradiate constrictions cross the flank and venter of the last half whorl. These constrictions and the bounding ribs are a little sinuous and arch forward on crossing the venter. One to three weaker secondary ribs are present on the outer half of the flank between each pair of constrictions.

Eopachydiscus marcianus attains a large size (Adkins and Winton, 1919, pl. 2, fig. 2). Cragin (1893, p. 237) mentioned that some specimens attain a diameter of about 2 feet $(610 \mathrm{~mm})$, and have whorl heights exceeding 8 inches $(200 \mathrm{~mm})$.

The types of Ammonites marcianus Shumard, $A$. brazoensis Shumard, and Pachydiscus laevicaniculatus Roemer came from the lower part of the Duck Creek Limestone in south-central and north-central Texas (Adkins, 1928 , p. 220,221 ), where $E$. marcianus occurs in such abundance as to be used in constructing gate posts and flower bed borders (Winton and Adkins, 1919, pl. 4, fig. 2).

Parts of 10 pachydiscids from locality D6830 can be assigned to $E$. marcianus. The smallest specimen (pl. 1 , figs. 3,6) has an estimated diameter of about $43 \mathrm{~mm}$.
Its whorls are well rounded and about as high as wide. The inner whorls are poorly preserved, but the last half of the outer whorl has about five constrictions crossing the outer part of the flanks and venter. A strong, thick rib arising from an umbilical bulla trends straight across the flank and venter and bounds one side of a constriction. This individual also has on the last half whorl five strong, straight ribs that begin from umbilical bullae. The rest of the specimens consist of larger fragments of only parts of whorls. As the whorls increase in size, they become higher than wide, and the venter becomes narrowly rounded. The largest fragment is part of a septate whorl that had an estimated height of $150 \mathrm{~mm}$. At that large size, broad, low ribs are present on the outer half of the flank, but they disappear on the venter. Fragments of two other septate specimens, which have whorl heights of 97 and $110 \mathrm{~mm}$, have sinuous constrictions and low ribs arching forward on crossing the venter. Whorl sections are typical of the species at these diameters (pl. 2, fig. 1).

Types.-Hypotypes, USNM 363030-363034.

\section{Family BRANCOCERATIDAE Spath, 1834 Subfamily MORTONICERATINAE Spath, 1925 Genus MORTONICERAS Meek, 1876}

Type species.-Ammonites vespertinus Morton, 1834.

This genus, proposed by Meek (1876, p. 448), has been broadly interpreted to include fairly evolute keeled ammonites that have squarish to rectangular whorl sections and ornament of bituberculate, trituberculate, or quadrituberculate ribs. Some forms have, in addition, spiral ornament. Rostrate apertures are common. Suture usually has rather deeply indented lobes and saddles; the $\mathrm{E} / \mathrm{L}$ saddle is broad and bifid, and $\mathrm{L}$ is narrower and bifid or irregularly trifid.

\section{Mortoniceras equidistans (Cragin)}

Plate 1, figure 8 ; plate 2 , figures 5,6 ; plate 3 , figures 4,5 ; plate 5 , figures $1-8$.

1893. Schloenbachia leonensis Conrad var. equidistans Cragin, p. 241.

1904. Schloenbachia kiliani Lasswitz, p. 245, pl. 19, fig. 1; text fig. 6.

1907. Mortoniceras inflatum (Sowerby) var. kiliani Lasswitz? Pervinquière, p. 246.

1910. Schloenbachia whitei Böse, p. 63, pl. 1, figs. 6-9.

1910. Schloenbachia trinodosa Böse, p. 78, pl. 9, fig. 4; pl. 10, figs. 1-4.

1922. Inflaticeras [Subschloenbachia] kiliani (Lasswitz). Spath, p. 102.

1923. Inflaticeras kiliani (Lasswitz). Spath, p. 76. 
1925. Schloenbachia (Inflaticeras) trinodosum Boese. Diener, p. 139.

1925. Schloenbachia (Inflaticeras) whitei Boese. Diener, p. 139

1925. Gauthiericeras kiliani (Lasswitz). Diener, p. 153.

1925. Inflaticeras kiliani (Lasswitz). Spath, p. 183.

1925. Inflaticeras trinodosum (Böse). Spath, p. 183.

1927. Pervinquieria kiliani (Lasswitz). Adkins, pl. 3, fig. 4.

1927. Schloenbachia trinodosa Böse. Bybee and Bullard, pl. 4, fig. 3 .

1928. Prohysteroceras whitei (Böse). Adkins, p. 229.

1928. Pervinquieria kiliani (Lasswitz). Adkins, p. 233, pl. 5, fig. 4.

1928. Pervinquieria n. sp. 4. Adkins, p. 234, pl. 10, fig. 1 .

1928. Pervinquieria trinodosa (Böse). Adkins, p. 234.

1932. Mortoniceras (Pervinquieria) kiliani (Lasswitz). Spath, p. 408 , pl. 38 , figs. 1,2 ; pl. 42 , fig. 1 ; pl. 47 , fig. 1 ; text fig. $14 \mathrm{C}$.

1934. Prohysteroceras (Goodhallites) whitei (Böse). Spath, p. 446.

1940. Pervinquieria kiliani (Lasswitz). Breistroffer, p. 75, 138.

1940. Pervinquieria kiliani var. alstonensis Breistroffer, p. $138,139$.

1940. Pervinquieria fallax var. kilianiformis Breistroffer, p. 140.

1942. Pervinquieria kiliani (Lasswitz). Haas, p. 94

1947. Neoharpoceras (Goodhallites) withei (sic) Böse. Breistroffer, p. 66.

1947. Pervinquieria kiliani (Lasswitz). Breistroffer, p. 66.

1955. Mortoniceras (Mortoniceras) kiliani (Lasswitz). Reyment, p. 33, pl. 5, fig. 3.

1957. Pervinquieria kiliani (Lasswitz). Young, p. 3.

1957. Goodhallites whitei (Böse). Young, p. 19.

1967a. Pervinquieria equidistans (Cragin). Young, p. 67-69.

1967b. Pervinquieria equidistans (Cragin). Young, p. 27.

The species equidistans was originally described as Schloenbachia leonensis Conrad var. equidistans Cragin (1893, p. 241$)$. The variety was briefly described as having ribs bearing "three coarse, equidistantly placed nodes: umbilical, intermediate, and ventro-lateral, of which the last-named is particularly large and prominent and, with the corresponding nodes of other ribs, gives to the venter a decidedly squarish, instead of the ordinary rounded appearance." Cragin did not illustrate the type. A single extant specimen in the Cragin collections at Colorado College, Colorado Springs, Colo., may be the holotype. This keeled specimen, $169 \mathrm{~mm}$ in diameter, has an umbilical ratio of 0.42 and a squarish whorl section a little higher than wide. Ornament consists of prorsiradiate ribs that have equispaced umbilical, lateral, and ventrolateral tubercles. Ribs are slightly sinuous on the penultimate whorl, where they number 35 . On the outer whorl, ribs are straight and number 22. Ventrolateral tubercles on the outer whorl are large and nodate to slightly clavate. Faint spiral ornament is present on the outer whorl.

The ammonite from Texas described as Schloenbachia kiliani Lasswitz (1904, p. 245, pl. 19, fig. 1; text fig. 6) can be interpreted as the inner whorls of the species $M$. equidistans. Lasswitz's type has a diameter of $94 \mathrm{~mm}$, an umbilical ratio of 0.36 , and a squarish whorl section a little higher than wide. Ornament consists of 40 slightly sinuous trituberculate ribs that have faint spiral ornament on the ventrolateral shoulder. Young (1967b, p. 27) regarded Lasswitz's species as a synonym of $M$. equidistans.

Two ammonites from the Ciudad Juarez area, Chihuahua, Mexico, described by Böse (1910) as Schloenbachia whitei and $S$. trinodosa, can also be included as synonyms of $M$. equidistans. The holotype of $S$. whitei (Böse, 1910, pl. 1, figs. 6-9) is half a whorl of a phragmocone about $84 \mathrm{~mm}$ in diameter. Whorl section is higher than wide and subrectangular with flattened flanks and venter. Greatest width is at the umbilical shoulder. A low keel is present. Ornament consists of closely spaced prorsiradiate sinuous ribs rising from umbilical bullae or from a position low on the flanks. All ribs are accentuated at the ventrolateral shoulder, where they bend forward onto the venter. The external suture (Böse, 1910, pl. 1, fig. 8) has a broad, bifid E/L saddle and a narrower, bifid, rectangular $\mathrm{L}$. The specimen came from rocks now assigned to the Smeltertown Formation in the Ciudad Juarez area, Chihuahua, Mexico (Strain, 1976, p. 78, 79).

Several specimens consisting of half a whorl or more, as well as fragments of $\mathbf{3 0}$ other specimens from USGS Mesozoic locality D6830, reveal that Böse's holotype of Schloenbachia whitei can be interpreted as the inner whorls of the form Böse named Schloenbachia trinodosa. The latter was based on two large phragmocones that have whorls higher than wide and are ornamented by prorsiradiate closely spaced to moderately spaced trinodose ribs. The change in ornament from that of forms like the holotype of $S$. whitei to that of $S$. trinodosa can be seen best on a specimen from locality D6830 (pl. 1, fig. 8). This individual consists of an adult phragmocone with part of the body chamber present. The early part of the outer septate whorl has flattened flanks ornamented by closely spaced prorsiradiate sinuous ribs numbering 28 per half whorl. These ribs rise from umbilical bullae or from a position low on the flanks. Each rib is accentuated at the ventrolateral shoulder. On the later part of the last septate whorl, ribs become more widely spaced and straighter, and a bullate tubercle arises on each at the middle of the flank. Whorl height at the base of the body chamber is about $55 \mathrm{~mm}$. Several other specimens in the collections are septate at whorl heights of $50-60 \mathrm{~mm}$. Sutures of the specimens from locality D6830 are like that of the holotype of Böse's Schloenbachia whitei. 
The juvenile closely spaced flexuous ribs of $M$. equidistans are much like those of the species described as Schloenbachia burckhardti by Böse $(1910$, p. 61 , pl. 1 , figs. $1,2,4,5$ ), but the latter has an entirely different suture characterized by a long narrow $\mathrm{L}$.

The inner whorls of $M$. equidistans in their compressed, flat flanks and closely spaced, sinuous, weakly bituberculate ribs closely resemble the inner whorls of Prohysteroceras Spath (1921, p. 286), especially the subgenus Goodhallites Spath (1932, p. 381). Most species of Mortoniceras have inner whorls ornamented by fewer, stronger, and straighter ribs, but some species have densely and sinuously ribbed inner whorls, such as $M$. fissicostatum Spath (1932, p. 396), and $M$. sp. ex gr. pricei (Spath) as figured by Renz (1971, pl. 11, figs. 3a, b).

In addition to the specimens from locality D6830, several specimens were found at localities D10184 and D11759.

Types.-Hypotypes, USNM 363039-363044.

\section{Mortoniceras aff. M. leonense (Conrad)}

Plate 3, figures 1, 2, 6-10, 12, 13

Many fragments of robust ammonites from USGS Mesozoic localities D6830 and D6832 have affinities with Mortoniceras leonense (Conrad, 1857, p. 160, pl. 16, fig. 2a-d). Conrad's holotype, described as Ammonites leonensis, came from unnamed rocks near Leon Springs, Pecos County, Texas, which Adkins (1927, p. 67) later assigned to the Duck Creek Limestone.

Mortoniceras leonense is characterized by its squarish whorl section, sparse ribbing, and prominent umbilical and ventrolateral tubercles. The type (USNM 9878) is in the National Museum of Natural History, Washington, D.C. A plaster cast of the type shows it to consist of a whorl and a half of a phragmocone that has a diameter of about $83 \mathrm{~mm}$ and an umbilical ratio of 0.43 . On the outer whorl, 21 straight, rectiradiate ribs bear strong, nodate inner ventrolateral tubercles. Umbilical tubercles are strong and nodate, and number 13 per whorl. Ribs alternate in length on the younger third of the outer whorl, where the long ones arise from the umbilical tubercles, and the shorter ones begin near the middle of the flank. On the rest of the outer whorl, most ribs arise in pairs from the umbilical tubercles. Weak midflank tubercles are present on several ribs on the younger half of the last whorl.

Several specimens from the Sarten Sandstone that have affinities with $M$. leonense consist of parts of whorls comparable in size to those of Conrad's holotype. The smallest specimen is half a whorl $41.5 \mathrm{~mm}$ in diameter that has an umbilical ratio of 0.40 and ornament of weak, straight ribs and 7 strong nodate umbilical tubercles and 12 strong inner ventrolateral tubercles (pl. 3, figs. 6, 7). A little larger specimen (pl. 3, figs. 1, 2) of $57 \mathrm{~mm}$ diameter has 25 ventrolateral and 13 umbilical tubercles on the outer whorl. Another specimen (pl. 3, figs. 8-10), consisting of parts of two whorls, has an umbilical ratio of 0.38 at a diameter of $57.5 \mathrm{~mm}$ for the smaller whorl. At this diameter 15 ventrolateral tubercles and 8 umbilical tubercles are present per half whorl. A fourth specimen (not illustrated) has 17 ventrolateral tubercles and about 9 umbilical tubercles per half whorl at a diameter of 89 mm. Weak mid-flank tubercles first appear on the Sarten specimens at some diameter near $50 \mathrm{~mm}$. These specimens from the Sarten Sandstone differ from the holotype of $M$. leonense mainly in having more ribs and tubercles.

Fragments of large, robust ammonites from USGS Mesozoic localities D6830, D10184, and D10520, may represent parts of adults of Mortoniceras aff. M. leonense. These fragments have squarish whorl sections and trinodose ribs (pl. 3, figs. 12, 13). Several septate fragments have whorl heights of more than $50 \mathrm{~mm}$. Ribs, which are rectiradiate to prorsiradiate, have equal-spaced nodate umbilical, lateral, and ventrolateral tubercles, of which the last is usually the largest.

Figured specimens.—USNM 363046-363049.

\section{Mortoniceras 8p.}

Plate 4, figures 14,15

A phragmocone from USGS Mesozoic locality D6830 resembles Mortoniceras equidistans in having trituberculate ribs, but the specimen is more involute, and the ribbing is sparser. The specimen consists of parts of two whorls. Ribs per half whorl are estimated at 16 or 17 for the inner whorl and 9 or 10 for the outer whorl.

Figured specimen.-USNM 363045.

\section{Subgenus DRAKEOCERAS Young, 1957}

Type species.—Drakeoceras drakei Young, 1957.

Young (1957, p. 19) proposed Drakeoceras for moderately evolute keeled ammonites that have densely ribbed inner whorls and more sparsely ribbed outer whorls. Ribs on the outer whorls have umbilical tubercles and usually double ventrolateral tubercles. Although Young erected Drakeoceras as a genus, ammonites of this 
type seem to fall within the scope of Mortoniceras as suggested by Matsumoto (1960, p. 38).

\section{Mortoniceras (Drakeoceras) sp.}

Plate 2, figures 2, 3; plate 3, figure 3; plate 4 , figure 13

An impression of a small part of a whorl and parts of distorted whorls of two other individuals from locality D6833 represent a species of Mortoniceras characterized by finely ribbed inner whorls and sparsely ribbed outer whorls. About 12 or 13 ribs are present per half whorl at diameters of $110-120 \mathrm{~mm}$. At this size, ribs consist of primaries separated by one or two secondaries. Primaries rise from strong umbilical tubercles, and secondaries appear low on the flanks. All ribs bear nodate ventrolateral tubercles, some of which consist of a double tubercle. The impressed area on the dorsum of one of the specimens reveals a densely ribbed venter on which the ribs are bent forward sharply as chevrons (pl. 3, fig. $3)$.

Owing to their fragmentary condition or to their great distortion, none of the specimens can be assigned with certainty to any described species. The lateral impression of one specimen (pl. 4, fig. 13) has ornament suggestive of the side view of Mortoniceras (Drakeoceras) lasswitzi (Young, 1957, pl. 5, fig. 5). The densely ribbed venter of the inner whorl of another specimen (pl. 3, fig. 3) is like the venter of $M$. (D.) dellense (Young, 1957, pl. 10, fig. 5) at a comparable diameter.

Figured specimens.-USNM 363050-363052.

\section{Family ACANTHOCERATIDAE Hyatt, 1900 Genus MANTELLICERAS Hyatt, 1803}

Type species._Ammonites mantelli J. Sowerby, 1814.

Kennedy $(1971$, p. 49, 50) summarized this genus as "Medium-sized (rarely large) ammonites, evolute and inflated to involute and compressed, usually with umbilical, lower lateral, lower and upper ventro-lateral tubercles on long ribs, alternating with short ribs with lower lateral and lower and upper ventro-lateral tubercles at some stage in the ontogeny. Some forms lose all but the upper ventrolateral tubercles early in their ontogeny and may become non-tuberculate when adult. Venter typically raised, but a siphonal tubercle is never developed. Suture-line relatively simple, with moderately subdivided rectangular bifid elements."

This early Cenomanian genus has a world-wide distribution.
Mantelliceras sp.

Plate 4, figures $1-10$

Parts of six specimens from the top of the Sarten Sandstone represent a robust, rather sparsely ribbed species of Mantelliceras. Most consist of less than half a septate whorl (pl. 4, figs. 1-10). All are stout and have whorl sections about as wide as high with broadly rounded to flattened flanks. Ribs are strong, straight, mostly rectiradiate, and of alternate long and short lengths. They number about 15 per half whorl. All specimens have bullate umbilical tubercles and nodate inner and outer ventrolateral tubercles of which the outer rise above the venter and are the stronger. On the large specimens, the inner ventrolateral tubercles weaken and disappear. The two smallest specimens have occasional very weak lateral tubercles. Sutures are poorly preserved.

Sparsely ribbed mantelliceratids may be characteristic of a high position in the lower Cenomanian. Kennedy (1971, pls. 20-22) illustrated several sparsely ribbed forms from the upper part of the lower Cenomanian of England. These specimens were referred to as Mantelliceras gr. dixoni Spath, $M$. tenue Spath, and $M$. aff. souaillonense (Renz).

Of the American species of Mantelliceras, $M$. budaense Adkins (1931, p. 41, pl. 2, fig. 3, pl. 4, fig. 10) resembles the fragments from the Sarten Sandstone in its robust form and sparse ribbing. The holotype of $M$. budaense, the only specimen described, came from the Buda Limestone near Austin, Texas. The specimen consists of about a third of a whorl of body chamber and the last septate whorl. Diameter of the type is 87 $\mathrm{mm}$, and the umbilical ratio is 0.32 . The body chamber is a little broader than high with broadly rounded flanks. Matsumoto (1960, fig. 3A) has shown a sketch of the whorl section. Ornament consists of rectiradiate to slightly prorsiradiate, strong, rounded, straight ribs that alternate in length and number 25 on the last complete whorl. Larger ribs arise from umbilical bullae, and all ribs have inner and outer nodate ventrolateral tubercles. In contrast to the ornament on the Sarten specimens, the inner ventrolateral tubercles on the holotype persist to a larger diameter. Young and Powell (1976, p. xxv.4, pl. 7, figs. $10,12)$ and Young $(1979$, p. $16,20,21,89)$ considered $M$. budaense as a synonym of $M$. cantianum Spath.

European species of Mantelliceras that lose the inner ventrolateral tubercles at a small diameter similar to that of the Sarten specimens include M. couloni (d'Orbigny, 1850, p. 147) and $M$. costatum (Mantell, 1822, p. 113, pl. 21, fig. 9). These species, however, are more densely ribbed than the Sarten species at comparable diameters.

Figured specimens.-USNM 363035-363038. 
Family ENGONOCERATIDAE Hyatt, 1800

Genus ENGONOCERAS Neumayr and Uhlig, 1881

Type species._Ammonites pierdenalis von Buch, 1849.

Engonoceras includes involute, compressed shells with flat or sulcate venter. Ribs are flexuous to straight and usually flattened on the outer part of the flank. Nodate to bullate umbilical and mid-flank tubercles may be present as well as ventrolateral clavi arranged alternately across the venter. Suture is simple with mostly entire saddles. The genus has a range of middle Albian to early Cenomanian.

\section{Engonoceras belviderense (Cragin)}

Plate 1, figure 7

1890. Ammonites belviderei Cragin, p. 75 (not described).

1894b. Ammonites belviderensis Cragin. Cragin, pl. 1, figs. 3-5 (not described).

1895. Sphenodiscus belviderensis (Cragin). Cragin, p. 369.

1898. Engonoceras belviderensis (Cragin). Böhm, p. 192.

1900. Buchiceras (Sphenodiscus) belviderensis (Cragin). Cragin, p. 27.

1900. Buchiceras (Sphenodiscus) belviderensis var. monscomancheanus Cragin, p. 29, pl. 1, fig. 5.

1900. Buchiceras (Sphenodiscus) belviderensis var. clavatus Cragin, p. 30, pl. 2, figs. 1-3.

1900. Buchiceras (Sphenodiscus) belviderensis var. uddeni Cragin, p. 30, pl. 1, figs. 3, 4 .

1900. Buchiceras (Sphenodiscus) belviderensis var. mentorianus Cragin, p. 31, pl. 1, figs. 6, 7.

1903. Engonoceras belviderense (Cragin). Hyatt, p. 158, pl. 18 , figs. $4,5$.

1903. Engonoceras uddeni (Cragin). Hyatt, p. 159, pl. 18, figs. $1-6$.

1924. Engonoceras belviderensis (Cragin). Twenhofel, p. 87, pl. 11, figs. 1-4.

1928. Engonoceras belviderense var. mons-comancheanum (Cragin). Adkins, p. 262.

1928. Engonoceras belviderense var. clavatum (Cragin). Adkins, p. 212.

1970. Engonoceras belviderense (Cragin). Scott, p. 83.

Scott $(1970$, p. 83$)$ has drawn attention to the variation within this species. Most names applied to the species were based on small variations in the suture. Specimens assigned to the species by Cragin are slender and weakly ornamented.

A single impression of part of a whorl from locality D6833 can be assigned to Engonoceras belviderense. The impression has a flat flank and narrow, flat venter. Umbilical bullae are present, but ornament other than sinuous growth striae is absent.

Type.-Hypotype, USNM 363053.

\section{Engonoceras sp.}

Plate 4, figures 11,12

Fragments of two moderately large poorly preserved engonoceratids are present in the collection from locality D6830. Each is represented by less than half a whorl of specimens that had diameters of about $68-70 \mathrm{~mm}$. Both specimens are robust, and have broad, flat venters bounded by alternate broad clavi numbering about 10 per whorl. Umbilical bullae number four per half whorl. Only bits of sutures are visible.

Figured specimen.-USNM 363054.

\section{Family TURRIITIDAE Meek, 1876} Genus TURRIIITES Lamarck, 1801

Type species.-Turrilites costatus Lamarck, 1801.

This helical genus is characterized by its tightly coiled spire that has an acute apical angle and is ornamented by ribs which may have three or four rows of equal numbers of tubercles. The genus may be confined to the Cenomanian.

\section{Turrilites aff. T. costatus Lamarck}

Plate 2, figure 4

A well-preserved turrilitid of four whorls was found at the contact of the Sarten Sandstone and the overlying Colorado Formation. The specimen was in a sandy, limy nodule that contained a few small chert pebbles. Inasmuch as the base of the Colorado Formation at this locality is a pebbly sandstone or a thin conglomerate, the question arises concerning the source of the turrilitid. Limestone nodules at the top of the Sarten are also sandy. Inasmuch as other fossils were not observed in the basal Colorado conglomerate, I am assuming the limy nodule containing the turrilitid was either at the very top of the Sarten or reworked into the base of the Colorado.

The turrilitid is an internal mold $96 \mathrm{~mm}$ high with an apical angle of $19^{\circ}$. Ornament consists of 22 strong, narrow, curved ribs on each whorl. On the middle of the whorls, the ribbing is interrupted by a narrow sulcus that may be pathologic.

Of the species of Turrilites, the Sarten specimen seems nearest to $T$. costatus Lamarck (1801, p. 102). Apical angle and rib density are similar to those of $T$. costatus. Turrilites costatus, however, has a more pronounced interruption in the ribbing a little below the middle of the flank as well as another interruption at the base, and the ribs between the two interruptions are nodelike.

Figured specimen.-USNM 363055. 


\section{REFERENCES CITED}

Adkins, W. S., 1927, The geology and mineral resources of the Fort Stockton quadrangle: University of Texas Bulletin 2738, 166 p., 6 pls.

1928, Handbook of Texas Cretaceous fossils: Texas University Bulletin 2838,385 p., 37 pls.

1931, Some Upper Cretaceous ammonites in western Texas: Texas University Bulletin 3101, p. 35-72, pls. 2-5.

Adkins, W. S., and Winton, W. M., 1919, Paleontological correlation of the Fredericksburg and Washita formations in north Texas: University of Texas Bulletin 1945, 128 p., 22 pls. [1920].

Amédro, Francis, 1980, Biostratigraphie de l'Aptien au Santonien dans le Boulonnais, in Robaszynski, Francis, and others, Synthèse biostratigraphique de l'Aptien au Santonien du Boulonnais à partir de sept groupes paléontologiques; foraminifères, nannoplancton, dinoflagellés et macrofaunes: Revue de Micropaléontologie, v. 22, no. 4, p. 230-258, pls. 7,8 .

Böhm, Johannes, 1898, Ueber Ammonites pedernalis v. Buch: Zeitschrift Deutschen Geologischen Gesellschaft, v. 50, p. 183-201, pls. 5-7.

Böse, Emil, 1910, Monographía geológica y paleontológica del Cerro de Muleros cerca de ciudad Juárez, Estado de Chihuahua, y descripción de la fauna cretácea de la Encantada, placer de Guadalupe, Estado de Chihuahua: Instituto Geológico de México Boletín 25, 193 p., 48 pls.

Brand, J. P., and DeFord, R. K., 1958, Comanchean stratigraphy of Kent quandrangle, Trans-Pecos Texas: American Association of Petroleum Geologists Bulletin, v. 42, no. 2, p. 371-386.

Breistroffer, Maurice, 1940, Révision des ammonites du Vraconien de Salazac (Gard) et considerations générales sur ce sous-étage Albien: Travaux du Laboratoire de Géologie de la Faculté des Sciences de l'Université de Grenoble, v. 22, p. $70-171$.

_ 1947, Sur les zones d'ammonites dans l'Albien de France et d'Angleterre: Travaux du Laboratoire de Géologie de la Faculté des Sciences de l'Université de Grenoble, v. 26, p. 17-104.

Buch, Leopold von, 1849, Über Ceratiten: Abhandlungen der Deutschen Akademie der Wissenschaften zu Berlin, Klasse für Mathematik und Allgemeine Naturwissenschaften, 1848, p. $1-30$.

Bullard, F. M., 1925, Geology of Love County, Oklahoma: Oklahoma Geological Survey Bulletin 33, 77 p., 29 pls.

1926, Geology of Marshall County, Oklahoma: Oklahoma Geological Survey Bulletin 39, 101 p., 21 pls.

Bybee, H. P., and Bullard, F. M., 1927, The geology of Cooke County, Texas: Texas University Bulletin 2710 , p. 5-61, 10 pls. [1928].

Clemons, R. E., 1982, Geology of Massacre Peak quadrangle, Luna County, New Mexico: New Mexico Bureau of Mines and Mineral Resources Geologic Map 51.

Conrad, T. A., 1857, Descriptions of Cretaceous and Tertiary fossils, in Emory, T. A., Report on the United States and
Mexican boundary survey, made under the direction of the Secretary of the Interior: U.S. 34th Congress 1st Session, Senate Executive Document 108, p. 141-174, 21 pls.

Cooper, M. R., and Kennedy, W. J., 1979, Uppermost Albian (Stoliczkaia dispar Zone) ammonites from the Angolan littoral: Annals of the South African Museum, v. 77, pt. 10, p. 175-308, 82 figs.

Cragin, F. W., 1890, On the Cheyenne Sandstone and the Neocomian Shales of Kansas: Washburn College Laboratory Natural History Bulletin 2, p. 69-80.

1893, A contribution to the invertebrate paleontology of the Texas Cretaceous: Texas Geological Survey 4th Annual Report, pt. 2, p. 139-246, pls. 24-46.

1894a, Descriptions of invertebrate fossils from the Comanche series in Texas, Kansas, and Indian Territory: Colorado College Studies, no. 5, p. 49-68.

1894b, New and little-known Invertebrata from the Neocomian of Kansas: American Geologist, v. 14, p. 1-12, pl. 1.

1895, A study of the Belvidere beds: American Geologist, v. 16, p. 357-385.

1900, Buchiceras (Sphenodiscus) belviderensis and its varieties: Colorado College Studies, v. 8, p. 27-31.

Darton, N. H., 1916, Geology and underground water of Luna County, New Mexico: U.S. Geological Survey Bulletin 618, $188 \mathrm{p}$.

1917, Description of the Deming quadrangle [N. Mex.]: U.S. Geological Survey Geologic Atlas, Folio 207, 15 p.

DeFord, R. K., and Haenggi, W. T., 1970, Stratigraphic nomenclature of Cretaceous rocks in northeastern Chihuahua, in Seewald, Ken, and Sundeen, Dan, eds., The geologic framework of the Chihuahua tectonic belt: West Texas Geological Society and University of Texas [Special publication], p. 175-196.

Diener, Carl, 1925, Ammonoidea neocretacea, Part 29 of Animalia, [Part] 1 of Diener, Carl, ed., Fossilium catalogus: Berlin, W. Junk, 244 p.

Haas, Otto, 1942, The Vernay collection of Cretaceous (Albian) ammonites from Angola: American Museum of Natural History Bulletin, v. 81, art. 1, p. 1-224, pls. 1-47.

Hazzard, R. T., 1959, The age of the yellowish marl above the Georgetown in northwestern Val Verde County and southwestern Crockett County, a discussion, in West Texas Geological Society Guidebook, Geology of the Val Verde Basin: p. $60-63$.

Huffington, R. M., 1943, Geology of the northern Quitman Mountains, Trans-Pecos Texas: Geological Society of America Bulletin, v. 54, p. 987-1048.

Hyatt, Alpheus, 1900, Cephalopoda, in Zittel, K. A. von, Textbook of palaeontology [1896-1900]: London, MacMillan, p. 502-604.

1903, Pseudoceratites of the Cretaceous, edited by $T$. W. Stanton: U.S. Geological Survey Monograph 44, 351 p., 47 pls.

Jicha, H. L., Jr., 1954, Geology and mineral deposits of Lake Valley quadrangle, Grant, Luna, and Sierra Counties, New Mexico: New Mexico Bureau of Mines and Mineral Resources Bulletin 37, 93 p. 
Kennedy, W. J., 1969, The correlation of the Lower Chalk of south-east England: Proceedings of the Geologists' Association [London], v. 80 , pt. 4, p. 459-560, pls. 15-22.

1970, A correlation of the uppermost Albian and the Cenomanian of south-west England: Proceedings of the Geologists' Association [London], v. 81, pt. 4, p. 613-677.

1971, Cenomanian ammonites from southern England: Palaeontological Association of London Special Papers in Palaeontology 8, 133 p., 64 pls.

Lamarck, J. B. P. A., de, 1801, Système des animaux sans vertèbres: Paris, J. B. P. A. de Lamarck, Chez Deterville, $432 \mathrm{p}$.

Lasswitz, Rudolf, 1904, Die Kreide-Ammoniten von Texas: Geologische und Palaeontologische Abhandlungen, n. ser., v. 6 , no. 4 , p. $222-259$, pls. $13-20$.

Mancini, E. A., 1979, Late Albian and early Cenomanian Grayson ammonite biostratigraphy in north-central Texas: Journal of Paleontology, v. 53, no. 4, p. 1013-1022.

1982, Early Cenomanian cephalopods from the Grayson Formation of north-central Texas: Cretaceous Research, v. 3, p. 241-259.

Mantell, Gideon, 1822, The fossils of the South Downs, or illustrations of the geology of Sussex: London, Lupton Relfe, 327 p., 42 pls.

Martin, K. G., 1967, Stratigraphy of the Buda Limestone, south-central Texas, in Hendricks, Leo, ed., Comanchean (Lower Cretaceous) stratigraphy and paleontology of Texas: Permian Basin Section of Society of Economic Paleontologists and Mineralogists Publication 67-8, p. 287-299.

Matsumoto, Tatsuro, 1960, On some type ammonites from the Gulf Coast Cretaceous: Kyushu University Faculty of Science, Science Reports, Geology, v. 5, no. 1, p. 36-49. [In Japanese.]

Matsumoto, Tatsuro, Muramoto, Tatsuo, and Takahashi, Takemi, 1969, Selected acanthoceratids from Hokkaido: Kyushu University Faculty of Science Memoirs, Series D, Geology, v. 19, no. 2, p. 251-296, pls. 25-38.

Meek, F. B., 1876, A report on the invertebrate Cretaceous and Tertiary fossils of the upper Missouri country: U.S. Geological Survey of the Territories (Hayden) Report 9, 629 p., 45 pls.

Moore, C. H., Jr., 1969, Stratigraphic framework, Lower Cretaceous, west-central Texas, in Moore, C. H., ed., A guidebook to the depositional environments and depositional history Lower Cretaceous shallow shelf carbonate sequence, west-central Texas: Dallas Geological Society, p. 1-16.

Morton, S. G., 1834, Synopsis of the organic remains of the Cretaceous group in the United States: Philadelphia, Key \& Biddle, 88 p., 19 pls.

Neumayr, M., and Uhlig, V., 1881, Ueber Ammonitiden aus dem Hilsbildungen Norddeutschlands: Palaeontographica, v. 27, p. 129-203, pls. 15-57.

Orbigny, Alcide d', $1850-52$, Prodrome de paléontologie stratigraphique universelle des animaux mollusques et rayonnés, volume 2: Paris, V. Masson, 428 p.

Owen, H. G., 1975, The stratigraphy of the Gault and Upper Greensand of the Weald: Proceedings of the Geologists' Association [London], v. 86 , pt. 4 , p. $475-498$.
Perkins, B. F., 1960, Biostratigraphic studies in the Comanche (Cretaceous) Series of northern Mexico and Texas: Geological Society of America Memoir 83, 138 p., 34 pls.

Pervinquiere, Léon, 1907, Études de paléontologie tunisienne, Part 1, Céphalopodes des terrains secondaires: Carte Géologique Tunisie, 438 p., 27 pls.

Reaser, D. F., 1970, Preliminary study of the Buda Limestone in foothills of the southern Quitman Mountains, Trans-Pecos Texas, in Geology of the southern Quitman Mountains area, Trans-Pecos Texas: Permian Basin Section of Society of Economic Paleontologists and Mineralogists Publication 70 12 , p. 76-81.

Reeside, J. B., Jr., 1923, The fauna of the so-called Dakota formation of northern central Colorado and its equivalent in southeastern Wyoming: U.S. Geological Survey Professional Paper 131-H, p. 199-207, pls. 45-50.

Renz, Otto, 1971, Die Gattungen Hysteroceras Spath und Mortoniceras Meek (Ammonoidea) aus den Anden Venezuelas: Eclogae Geologicae Helvetiae, v. 64, no. 3, p. 569-609, 11 pls.

Reyment, R. A., 1955, The Cretaceous Ammonoidea of southern Nigeria and the southern Cameroons: Geological Survey of Nigeria Bulletin 25, 112 p., 25 pls.

Rose, P. R., 1972, Edwards Group, surface and subsurface, central Texas: Texas Bureau of Economic Geology Report of Investigations 74, $198 \mathrm{p}$.

Scott, R. W., 1970, Paleoecology and paleontology of the Lower Cretaceous Kiowa Formation, Kansas: University of Kansas Paleontological Contributions, Article 52 (Cretaceous 1$), 94$ p., 7 pls.

Sharpe, Daniel, 1853-56, Description of the fossil remains of Mollusca found in the Chalk of England: Palaeontographical Society [Monograph], 68 p., 27 pls.; 1853, p. 1-26, pls. $1-10$; 1854 , p. $27-36$, pls. $11-16$ [1855]; 1856 , p. $37-68$, pls. 17-27 [1857].

Shumard, B. F., 1854, Paleontology; description of the species of Carboniferous and Cretaceous fossils collected, in Marcy, R. B., Exploration of the Red River of Louisiana, in the year 1852: United States 33rd Congress, 2nd Session, Senate Executive Document 54, p. 197-211, 6 pls.

1860, Descriptions of new Cretaceous fossils from Texas: Transactions Academy of Science of St. Louis, v. 1, p. 590-610.

Sowerby, James, 1812-22, The mineral conchology of Great Britain: London, B. Meredith, 1812, v. 1, p. 9-32, pls. $1-9$; 1813 , v. 1 , p. $33-96$, pls. $10-44 ; 1814$, v. 1 , p. $97-$ 178 , pls. $45-78 ; 1815$, v. 1 , p. $179-234$, pls. $79-102$, and v. 2 , p. $1-28$, pls. $103-114$; 1816 , v. 2 , p. $29-116$, pls. $115-150 ; 1817$, v. 2 , p. $117-194$, pls. $151-186$; 1818 , v. 2 , p. $195-235$, pls. $187-203$, and v. 3 , p. $1-40$, pls. 204 221 ; 1819 , v. 3, p. 41-98, pls. 222-253; 1820, v. 3, p. 99-126, pls. $254-271$; 1821 , v. 3, p. $127-184$, pls. $272-$ 306 , and v. 4 , p. $1-16$, pls. $307-318 ; 1822$, v. 4 , p. $17-$ 114, pls. 319-383.

Spath, L. F., 1921, On Cretaceous Cephalopoda from Zululand: South African Museum Annals, v. 12, pt. 7, no. 16, p. 217-321, pls. 19-26. 
1922, On Cretaceous Ammonoidea from Angola, collected by Professor J. W. Gregory, D. Sc., F. R. S.: Transactions of the Royal Society of Edinburgh, v. 53, pt. 1, no. 6 , p. 91-160, 4 pls.

1923, Excursion to Folkstone, with note on the zones of the Gault: Proceedings of the Geologists' Association [London], v. 34, p. 70-76.

1925, On Upper Albian Ammonoidea from Portuguese East Africa, with an appendix on Upper Cretaceous ammonites from Maputoland: Annals of the Transvaal Museum, v. 11 , p. $179-200$, pls. $28-37$.

1926, On the zones of the Cenomanian and the uppermost Albian: Proceedings of the Geologists' Association [London], v. 37, pt. 4, p. 420-432.

1932, A monograph of the Ammonoidea of the Gault, pt. 9: Palaeontographical Society [London] Monograph, p. $379-410$, pls. $37-42$.

1934, A monograph of the Ammonoidea of the Gault, pt.11: Palaeontographical Society [London] Monograph, p. 443-496, pls. 49-56.

1942, A monograph of the Ammonoidea of the Gault, pt. 15: Palaeontographical Society [London] Monograph, p. 669-720.

Stanton, T. W., 1928, The Lower Cretaceous or Comanche series: American Journal of Science, 5th ser., v. 16, p. 399409.

Strain, W. S., 1968, Cerro de Muleros (Cerro de Cristo Rey), in Delaware Basin exploration, 1968 Guidebook: West Texas Geological Society Publication 68-55, p. 82.

1976, New formation names in the Cretaceous at Cerro de Cristo Rey, Dona Ana County, New Mexico, Appendix 2 in Lovejoy, E. M. P., Geology of Cerro de Cristo Rey uplift, Chihuahua and New Mexico: New Mexico Bureau of Mines and Mineral Resources Memoir 31, p. 77-82.

Twenhofel, W. H., 1924, The geology and invertebrate paleontology of the Comanchean and "Dakota" formations of Kansas: State Geological Survey of Kansas Bulletin 9, 135 p., 23 pls.

Underwood, J. R., Jr., 1963, Geologic map of Eagle Mountains and vicinity, Hudspeth County, Texas: Texas University Austin Bureau Economic Geology Quadrangle Map 26, scale 1:48,000 (reprinted 1974).

Winton, W. M., 1925, The geology of Denton County: University of Texas Bulletin 2544, 86 p., 21 pls.
Winton, W. M., and Adkins, W. S., 1919, The geology of Tarrant County: University of Texas Bulletin 1931, 123 p., 6 pls. [1920]

Wright, C. W., 1955, Notes on Cretaceous ammonites, II, The phylogeny of the Desmocerataceae and the Hoplitaceae: Annals and Magazine of Natural History, ser. 12, v. 8, p. 561-575.

1957a, Family Brancoceratidae Spath, 1933, in Arkell, W. J., and others, Mesozoic Ammonoidea, in Moore, R. C., ed., Treatise on invertebrate paleontology, Part L, Mollusca 4: New York and Lawrence, Kansas, Geological Society of America and University of Kansas Press, p. L402L409.

1957b, Family Pachydiscidae Spath, in Arkell, W. J., and others, Mesozoic Ammonoidea, in Moore, R. C., ed., Treatise on invertebrate paleontology, Part L, Mollusca 4: New York and Lawrence, Kansas, Geological Society of America and University of Kansas Press, p. L377-L381.

Young, Keith, 1957, Upper Albian (Cretaceous) Ammonoidea from Texas: Journal of Paleontology, v. 31, no. 1, p. 1-33, 10 pls. (reprinted as Texas University, Bureau of Economic Geology Report of Investigations 28).

1959, Index fossils of the Trans-Pecos area, in West Texas Geological Society Guidebook, Geology of the Val Verde Basin: p. 79-84.

1967a, Ammonite zonations, Texas Comanchean (Lower Cretaceous), in Hendricks, Leo, ed., Comanchean (Lower Cretaceous) stratigraphy and paleontology of Texas: Permian Basin Section of Society of Economic Paleontologists and Mineralogists Publication 67-8, p. 65-70.

1967b, Comanche Series (Cretaceous), south central Texas, in Hendricks, Leo, ed., Comanchean (Lower Cretaceous) stratigraphy and paleontology of Texas: Permian Basin Section of Society of Economic Paleontologists and Mineralogists Publication 67-8, p. 9-29.

-1972, Cretaceous paleogeography; implications of endemic ammonite faunas: Texas University, Bureau of Economic Geology Geological Circular 72-2, 13 p.

1979, Lower Cenomanian and late Albian (Cretaceous) ammonites, especially Lyelliceridae, of Texas and Mexico: Texas Memorial Museum Bulletin 26, 99 p., 9 pls.

Young, Keith, and Powell, J. D., 1976, Late Albian-Turonian correlations in Texas and Mexico, in Mid-Cretaceous events, Uppsala-Nice symposium, 1975-1976: Annales du Muséum d'Histoire Naturelle de Nice, v. 4, p. xxv.1xxv.36, 9 pls. [1978]. 


\section{INDEX}

[Italic page numbers indicate major references]

Acanthoceratidae ............ 9

Access to collecting localities ........ 2

adkinsi, Graysonites ............4

Adkinsites ................. . 4

bravoensis .............. 4

Advice concerning Sarten Sandstone ammonites ........... 2

aequatoriale, Mortoniceras ......... 4

Age of Sarten Sandstone .......... 4

alstonensis, Pervinquieria kiliani ... . . 7

Ammonite faunas of New Mexico and Texas 3

Ammonite zone for early Cenomanian of southern England .......... 4

Ammonite zones for upper Albian and Cenomanian rocks of Texas .... 4

for upper Albian of southern England . 4

Ammonites belviderei .......... 10

belviderensis ............. 10

brazoensis ............... 5

leonensis ............... 8

mantelli ................ 9

marcianus .............. 5

pierdenalis ............. 10

vespertinus ............. 6

Ammonites from Ciudad Juarez, Mexico . 7

from lower Cenomanian of England . . 9

Anapra Sandstone ............. 3

Anglo-Paris basin ..............4 4

Arrhaphoceras .............. 4

substuderi .............. 4

Artica compacta ............... 3

auritus, Callihoplites .......... 5

\section{B}

belviderei, Ammonites ........... 10

belviderense, Engonoceras ..... 10, pl. 1 clavatum, Engonoceras ........ 10 mons-comancheanum, Engonoceras . . 10

belviderensis, Ammonites ......... 10

Buchiceras (Sphenodiscus) ....... 10

clavatus .............. 10

mentorianus ........... 10

mons-comancheanus ........ 10

uddeni ............... 10

Engonoceras ............. 10

Sphenodiscus ............ 10

blancheti, Stoliczkaia (Faraudiella) .... 5

Boracho Limestone, Levinson Member . . 4

Böse, E., Cretaceous lithologic units of . 3

Brancoceratidae ............66

bravoensis, Adkinsites .......... 4

brazoense, Desmoceras ........ 4, 5

Eopachydiscus .......... 4, 6

brazoensis, Ammonites ............ 5

Eopachydiscus .......... 4, 6

Pachydiscus ............. 5

brazosensis, Eopachydiscus ...... 3, 4
Plesioturrilites ........... 4 brundrettei, Forbesiceras ..........4 4 Buchiceras (Sphenodiscus) belviderensis . 10 clavatus ............. 10 mentorianus ............ 10 mons-comancheanus ........ 10 uddeni ................ 10

Buda Limestone . . . . . . . . . . . . . . . 2, 9 budaense, Granocardium (Criocardium) . 3

Mantelliceras ........... 2, 9 budaensis, Homomya ........... 3 Budaiceras .............. 3, 4 hyatti ............... 3, 4 burckhardti, Schloenbachia ........8

\section{C}

Callihoplites .............. 4 auritus .................. 5 cantianum, Mantelliceras ........ 2, 9 carcitanensis, Hypoturrilites ..... 3, 4 clarki, Exogyra ............. 3 clavatum, Engonoceras belviderense ... 10 clavatus, Buchiceras (Sphenodiscus) belviderensis ........... 10

Cobban, R.R., collector ......... 2 Collecting locality, access ........ 2 Colorado Formation ... . . . . . . . . 10 compacta, Artica ............ 3 Cooke Range ................ costatum, Mantelliceras .......... 9 costatus, Turrilites ....... 3, 10, pl. 2 couloni, Mantelliceras ........... 9 (Criocardium) budaense, Granocardium . 3 Cymatoceras sp ............. 3

\section{D}

Del Rio Clay ............... 3 dellense, Mortoniceras (Drakeoceras) . . . 9 Descriptions, systematic .........5 Desmoceras brazoense ..........4, 5 laevicaniculatum ........... 6 laevicaniculatus ............ 4 marcianum .............. 6 sp. A ................ 5 dispar, Stoliczkaia ........... 5 dixoni, Mantelliceras........ . 3, 4, 9 drakei, Drakeoceras ... . . . . . . . . 4 Drakeoceras ......... 2, 4, 5,8 drakei ............... 4 lasswitzi .............. . 4 (Drakeoceras), Mortoniceras ... . 5, pl. 2 dellense............... 9

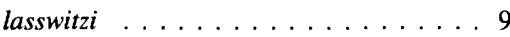
sp ........... 9, pl. 3, pl. 4 Duck Creek Formation ......... 3, 4 Duck Creek Limestone ........... 8 (Durnovarites) perinflatum, Mortoniceras . 5
E

Engonoceras .............. 10 belviderense .......... 10, pl. 1 clavatum ................. 10 mons-comancheanum ........ 10 belviderensis . . . . . . . . . . . . 10 uddeni ............... 10 sp ............ 2, 10, pl. 3

Engonoceratidae ............ 10

Eopachydiscus .......... 2, 4, 5

brazoense ...........4,6

brazoensis ............. 4, 6

brazosensis ............. 3,4 laevicaniculatus ........... 6 laevicaniculum ............. 4 marcianus ... 2, 3, 4, 5, pls. 1, 2, 3 Eopachydiscus marcianus-Mortoniceras equidistans fauna ........ 3 in northeast New Mexico ......... 4 in $\mathrm{Texas} \ldots \ldots \ldots . \ldots 3$ in Trans-Pecos Texas ...........4 4 equidistans, Mortoniceras . . . 2, 3, 4, 6, 8 , pls. $1,2,3,5$

Pervinquieria .......... 3, 4

[Mortoniceras] . . . . . . . . . 4

Schloenbachia leonensis ........6 6

Espy Formation ............. 4

Exogyra ................. 2

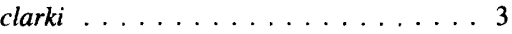
whitneyi ............... 3

\section{F, G}

fallax, Pervinquieria ......... 5 kilianiformis, Pervinquieria . . . . 7

Faraudiella ............... 3

(Faraudiella) blancheti, Stoliczkaia ... 5

Faunas, ammonite, of New Mexico and Texas ................ 3

fissicostatum, Mortoniceras ... . . . . 8

Fluorite Ridge ............... 1

Forbesiceras ............... 4

brundrettei ................ 4

Fort Worth Limestone ... . . . . . . . . 5

Gauthiericeras kiliani .......... 7

Goodhallites whitei ........... 7

(Goodhallites) withei, Neoharpoceras . . 7 whitei, Prohysteroceras ........ 7 Granocardium (Criocardium) budaense . . 3 Grayson Formation ............ 3 Graysonites ............... . 4 adkinsi ................. 4 lozoi .................. 4

\section{H-K}

harrisi, Tylostoma .......... 3

Homomya budaensis ........... 3

Hook, S.C., collector ........... 2 
hyatti, Budaiceras ........ 3, 4

Hypoturrilites carcitanensis . . . . . 3, 4

Hysteroceras . . . . . . . . 3, 4

orbignyi ............ 5

varicosum . . . . . . . . . 5

inflata, Pervinquieria .......5

Inflaticeras kiliani $\ldots \ldots \ldots \ldots \ldots 6$

trinodosum . . . . . . . . . . 7

[Subschloenbachia] kiliani .......6 6

(Inflaticeras) trinodosum, Schloenbachia . 7

whitei, Schloenbachia ........7

inflatum, Mortoniceras ........5

kiliani, Mortoniceras .........6

kiliani, Gauthiericeras . . . . . . . 7

Inflaticeras . . . . . . . . . 6

[Subschloenbachia $] \ldots \ldots \ldots \ldots 6$

Mortoniceras ............4 4

(Mortoniceras) . . . . . . . 7

(Pervinquieria) ........... 7

Mortoniceras inflatum .......6 6

Pervinquieria ......... 4, 7

Schloenbachia .............6 6

alstonensis, Pervinquieria . . . . . 7

kilianiformis, Pervinquieria fallax . . . 7

\section{L}

laevicaniculatum, Desmoceras . . . . . 6

laevicaniculatus, Desmoceras . . . . . 4

Eopachydiscus ..........6 6

Pachydiscus ............5

laevicaniculum, Eopachydiscus . . . . 4

Landis, E.R., collector . . . . . . . . 2

lasswitzi, Drakeoceras . . . . . . . . 4

Mortoniceras (Drakeoceras) . . . . . . .99

leonense, Mortoniceras ...... 8, pl. 3

leonensis, Ammonites .........8 8

equidistans, Schloenbachia . . . . 6

Levinson Member of Boracho Limestone . 4

Lima shumardi . . . . . . . . . . . . 3

lozoi, Graysonites ...........4

lymense, Mantelliceras ......... 3

\section{$\mathbf{M}$}

mantelli, Ammonites . . . . . . . . . 9

Mantelliceras . . . . . . . . 3,4

Mantelliceras . . . . . . . . . 2, 9

budaense . . . . . . . . 2, 9

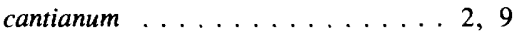

costatum ............. 9

couloni .............. 9

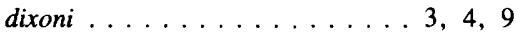

lymense . . . . . . . . . . . . 3

mantelli . . . . . . . . . 3, 4

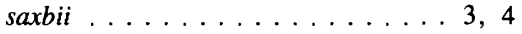

souaillonense ......... 3, 9

tenue .............. 9

sp . . . . . . . . . 9, pl. 3

Manuaniceras . .......... 4

powelli ............. 4

marcianum, Desmoceras . . . . . . 6

marcianus, Ammonites . . . . . . . . . 5

Eopachydiscus . 2, 3, 4, 5, pls. 1, 2, 3

Pachydiscus ............5 mentorianus, Buchiceras (Sphenodiscus)

belviderensis .......... 10

Merewether, E.A., collector . . . . . . . . 2

Mesa Rica Sandstone ........... 4

Mexico ............... 2, 7

mons-comancheanum, Engonoceras

belviderense ........... 10

mons-comancheanus, Buchiceras

(Sphenodiscus) belviderensis . . 10

Mortoniceras . . . . . . . . . 2, 4,6

aequatoriale ............. 4

equidistans . . . . . 2, 3, 4, 6, 8,

pls. $1,2,3,5$

fissicostatum ............. 8

inflatum ............. 5

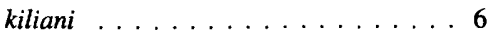

kiliani ................ 4

leonense .......... 8, pl. 3

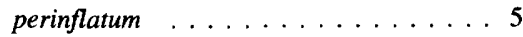

pricei ............... 8

wintoni ............... 4

sp ............. 8, pl. 4

(Drakeoceras) ......... 2, 5, pl. 2

dellense ............. 9

lasswitzt ................. . 9

sp .......... 9, pl. 3, pl. 4

(Durnovarites) perinflatum ....... 5

(Mortoniceras) kiliani .......... 7

(Pervinquieria) kiliani ........7 7

(Mortoniceras) kiliani, Mortoniceras ... . 7

[Mortoniceras] equidistans, Pervinquieria . 4

Mortoniceratinae ..............6 6

\section{$\mathrm{N}, \mathrm{O}$}

Naff, Richard, collector . . . . . . . . . 2

Neithea (Neithea) texana . . . . . . . . . 3

(Neithea) texana, Neithea ........ 3

Neoharpoceras (Goodhallites) withei . . . 7

nodosa, Schloenbachia .......... 3

orbignyi, Hysteroceras .......... 5

\section{P-R}

Pachydiscidae ............. 5

Pachydiscus brazoensis ......... 5

laevicaniculatus .............5

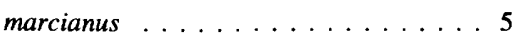

sp ................ 5

perinflata, Pervinquieria .......5

perinflatum, Mortoniceras ....... 5

(Durnovarites) ............ 5

Pervinquieria ............ 4

Pervinquieria equidistans ....... 3, 4

fallax ................ 5

kilianiformis .......... 7

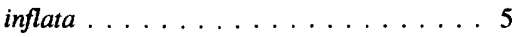

kiliani .............44,7

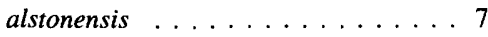

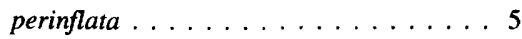

pricei ............... 5

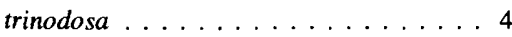

whitei .............. 4

n. sp. $4 \ldots \ldots \ldots \ldots \ldots$

[Mortoniceras] equidistans ....... 4
(Pervinquieria) kiliani, Mortoniceras . . 7

Photographing of specimens ........ 2

pierdenalis, Ammonites ........ 10

Plesioturrilites ............. 4

brazosensis ............. 4

powelli, Manuaniceras............. 4

pricei, Mortoniceras .......... 8

Pervinquieria ........... 5

Prohysteroceras whitei ........ 7

(Goodhallites) whitei ........ 7

Protocardia sp ............. 3

Pterotrigonia (Scabrotrigonia) sp ..... 3

Rattlesnake Ridge............. 1

Sarten Ridge ................ . 1 saxbii, Mantelliceras .......... 3, 4 (Scabrotrigonia) sp., Pterotrigonia . . . 3, 4 scheuchzerianus, Turrilites ........ 3 Schloenbachia burckhardti ........8 8

kiliani ............... 6

leonensis equidistans ......... 6

nodosa ............... 3

trinodosa ............. 3, 6

whitei .............. 6

(Inflaticeras) trinodosum ........ 7

whitei ............. 7

semiatimgranulata, Turritella ...... 3

shumardi, Lima . . . . . . . . . . . 3

Sierra de Cristo Rey uplift, Böse's

lithologic units on ....... 3

Smeltertown Formation .......... 3

souaillonense, Mantelliceras ..... . 3, 9

Sphenodiscus belviderensis . . . . . . 10

(Sphenodiscus) belviderensis, Buchiceras 10

clavatus .............. 10

mentorianus ............ 10

mons-comancheanus ........ 10

uddeni ............... 10

Stanton, T.W., quoted .......... 1

Stearnsia sp ............... 3

Stoliczkaia .............. 4

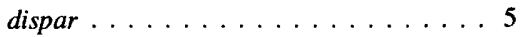

(Faraudiella) blancheti ......... 5

[Subschloenbachia] kiliani, Inflaticeras . . 6

substuderi, Arrhaphoceras ........ 4

Syncyclonema sp ............. 3

Systematic descriptions ......... 5

\section{$\mathrm{T}-\mathrm{Z}$}

Tabet, D.E., collector . . . . . . . . . 2 tenue, Mantelliceras ... . . . . . . . 9 texana, Neithea (Neithea) . . . . . . 3 Texas, Buda Limestone of ......... 2 trinodosa, Pervinquieria . . . . . . . 4, 7

Schloenbachia .......... 3, 6 trinodosum, Inflaticeras ........ 7

Schloenbachia (Inflaticeras) ...... 7

Turrilites .............. 10 costatus ........... 3, 10, pl. 2

scheuchzerianus ........... 3

Turrilitidae .............. 10 
Turritella semiatimgranulata ....... 3

sp ................. 3

Tylostoma harrisi ............ 3

uddeni, Buchiceras (Sphenodiscus) belviderensis .......... 10

Engonoceras ............. 10 varicosum, Hysteroceras ........ 5

vespertinus, Ammonites .........6 6
Washita Group ........... 1, 3 of Texas, upper Albian and

Cenomanian rocks in ...... 4

Weno Formation ............ 5

whitei, Goodhallites .......... 7

Pervinquieria ............ 4

Prohysteroceras ............ 7

(Goodhallites) ........... 7
Schloenbachia ............ 6

(Inflaticeras) ........... 7

whitneyi, Exogyra .......... 3

wintoni, Mortoniceras ......... 4

withei, Neoharpoceras (Goodhallites) . . 7

Wright, J.R., collector .......... 2

Young, Keith, quoted ......... 3 



\section{PLATES 1-5}

Contact photographs of the plates in this report are available, at cost, from the U.S.

Geological Survey Photographic Library, Federal Center, Denver, Colorado 80225 


\section{PLATE 1}

[All figures natural size. Localities shown on figure 1 in text]

Figures 1-6. Eopachydiscus marcianus (Shumard) (p. 5).

From USGS Mesozoic locality D6830.

1, 2. Hypotype USNM 363030.

3, 6. Hypotype USNM 363031 .

4, 5. Hypotype USNM 363032.

7. Engonoceras belviderense (Cragin) (p. 10).

Hypotype USNM 363053, from USGS Mesozoic locality D6833.

Lateral view with venter on left.

8. Mortoniceras equidistans (Cragin) (p. 6).

Hypotype USNM 363039, from USGS Mesozoic locality D6830.

See plate 5 , figure 8 , for rear view. 


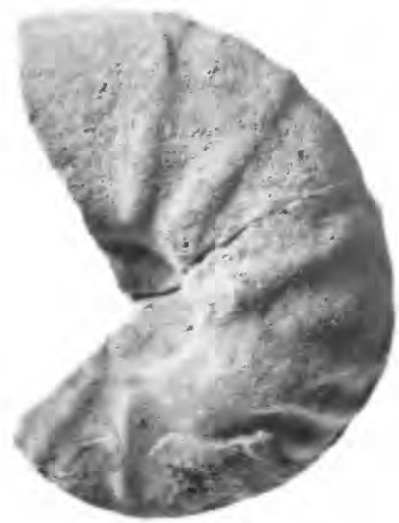

1

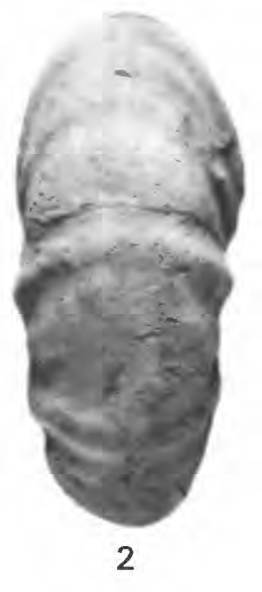

2
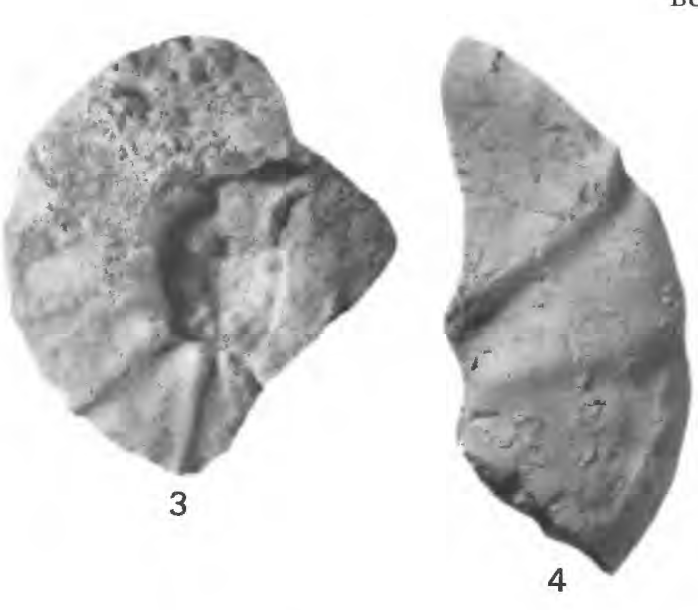

4

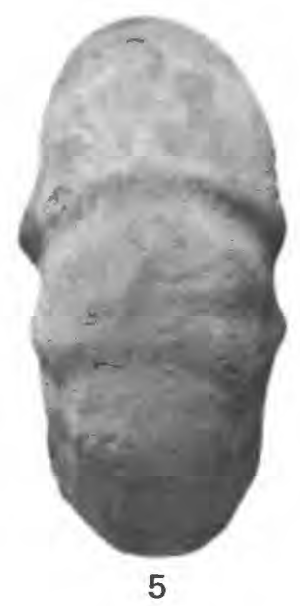

5

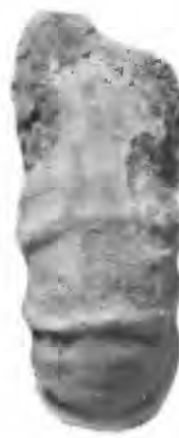

6
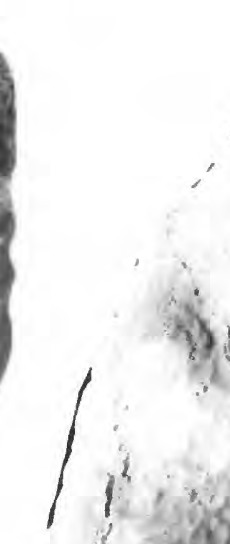

EOPACHYDISCUS, ENGONOCERAS, AND MORTONICERAS 


\section{PLATE 2}

[All figures natural size. Localities shown on figure 1 in text]

Figure 1. Eopachydiscus marcianus (Shumard) (p. 5). Hypotype USNM 363033, from USGS Mesozoic locality D6830.

2, 3. Mortoniceras (Drakeoceras) sp. (p. 9).

Figured specimen USNM 363050, from USGS Mesozoic locality D6833.

4. Turrilites aff. T. costatus Lamarck (p. 10).

Figured specimen USNM 363055, from USGS Mesozoic locality D10495.

5, 6. Mortoniceras equidistans (Cragin) (p. 6).

Hypotype USNM 363040, from USGS Mesozoic locality D6830. 

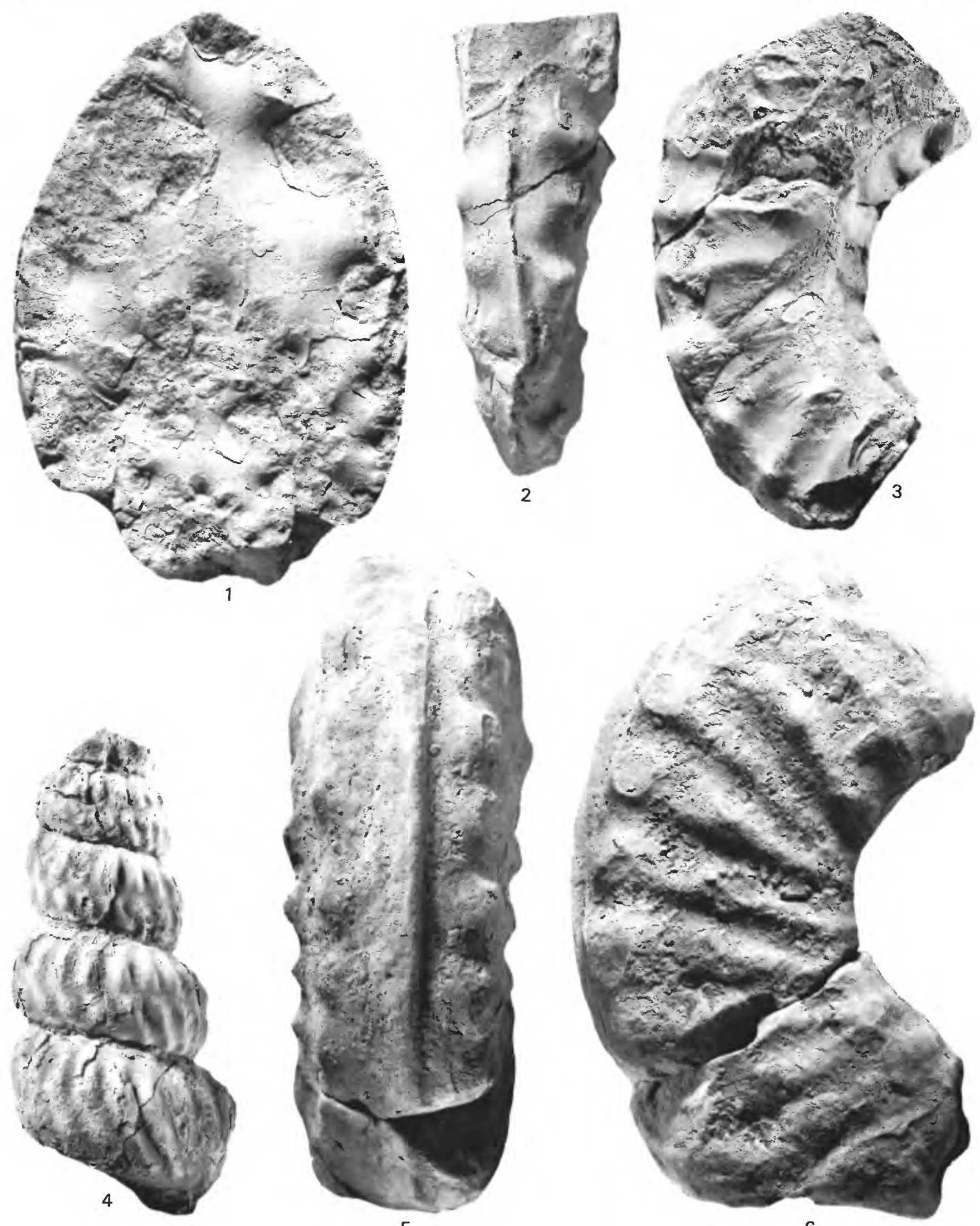

EOPACHYDISCUS, MORTONICERAS, AND TURRILITES 


\section{PLATE 3}

[All figures natural size. Localities shown on figure 1 in text]

Figures 1, 2, 6-10, 12, 13. Mortoniceras aff. M. leonense (Conrad) (p. 8).

1, 2. Figured specimen USNM 363046, from USGS Mesozoic locality D6830.

6, 7. Figured specimen USNM 363047, from USGS Mesozoic locality D6832.

8-10. Figured specimen USNM 363048, from USGS Mesozoic locality D6830.

12, 13. Figured specimen USNM 363049, from USGS Mesozoic locality D6830.

3. Mortoniceras (Drakeoceras) sp. (p. 9).

Latex cast of the venter of the inner whorls. Figured specimen USNM 363052, from USGS Mesozoic locality D6833.

4, 5. Mortoniceras equidistans (Cragin) (p. 6).

Hypotype USNM 363041, from USGS Mesozoic locality D6830.

11. Eopachydiscus marcianus (Shumard) (p. 5).

Hypotype USNM 363034, from USGS Mesozoic locality D6830. 
U.S. GEOLOGICAL SURVEY
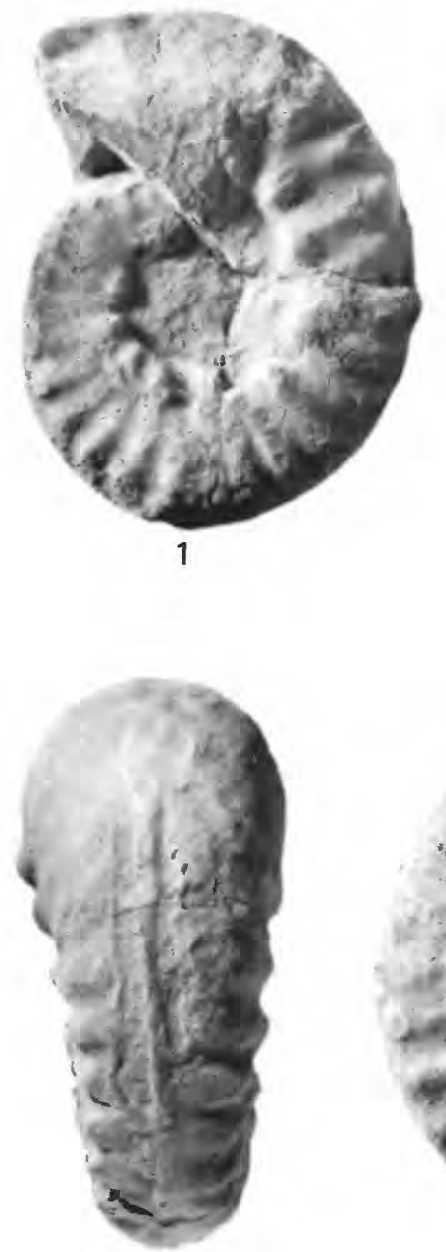

8
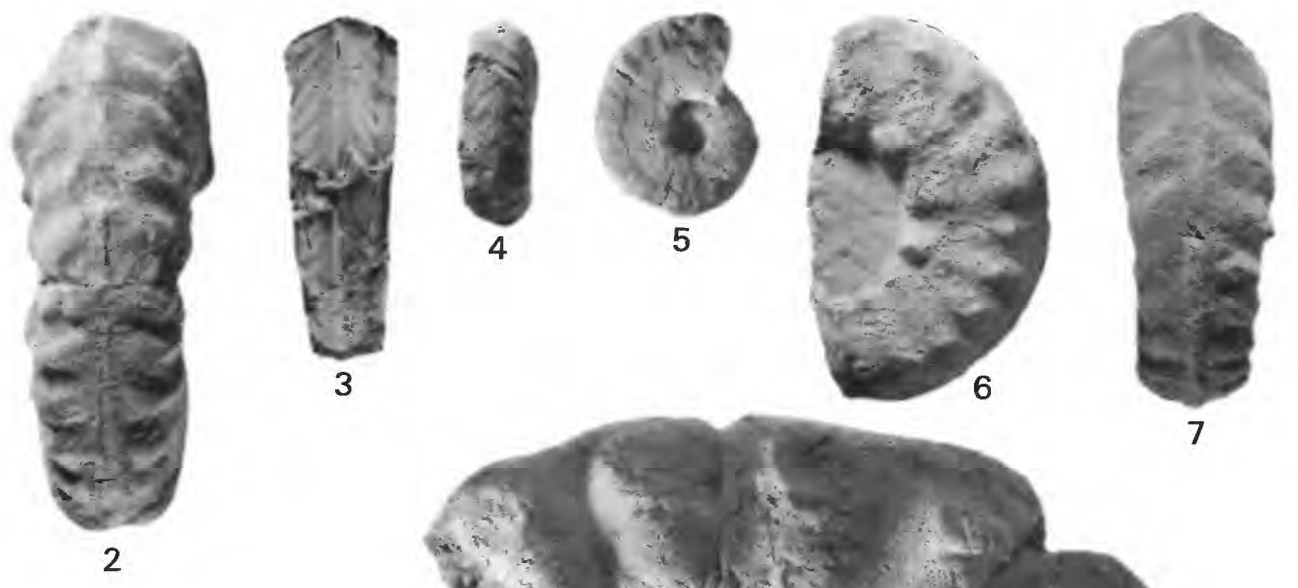

2
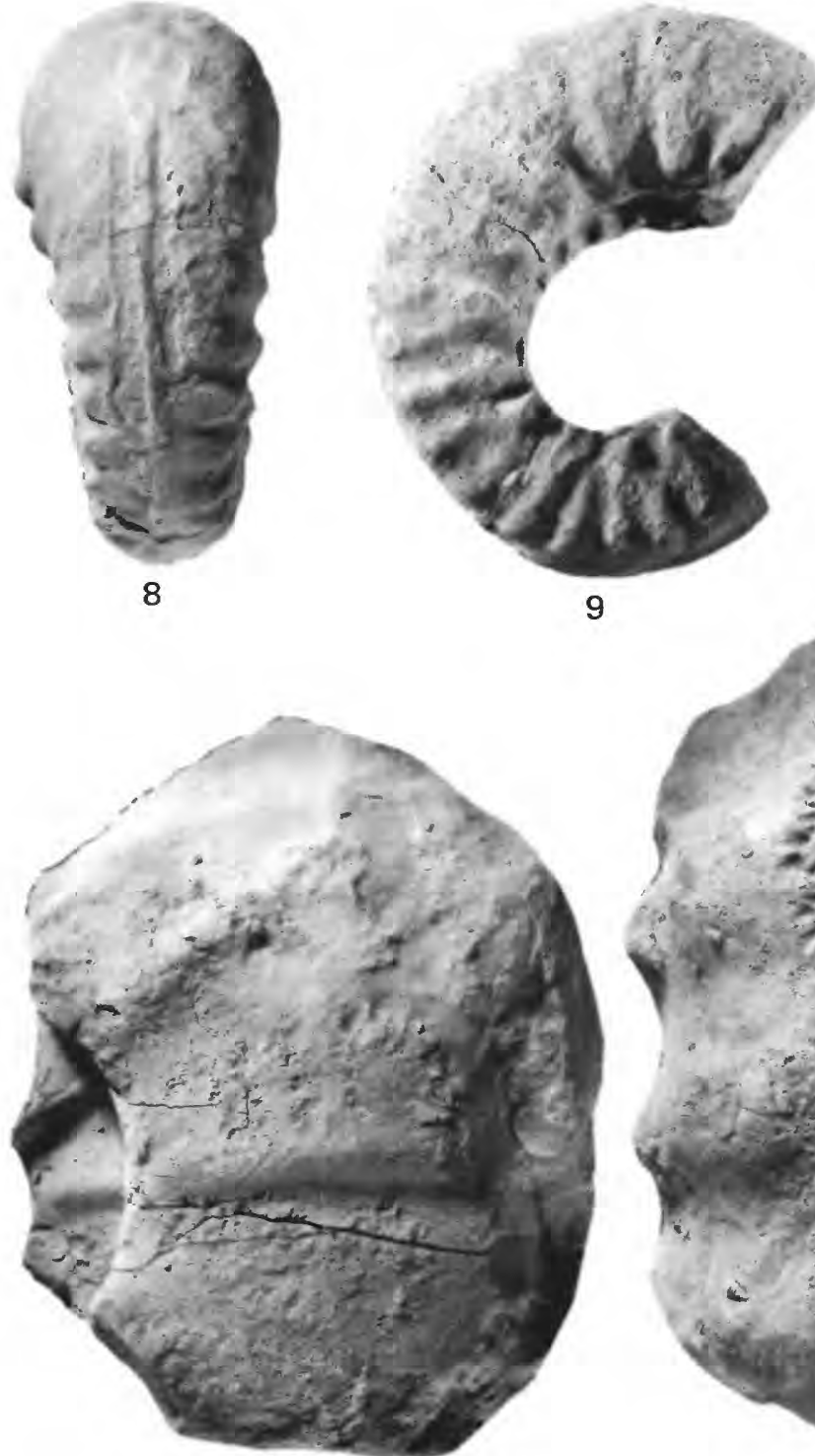

11

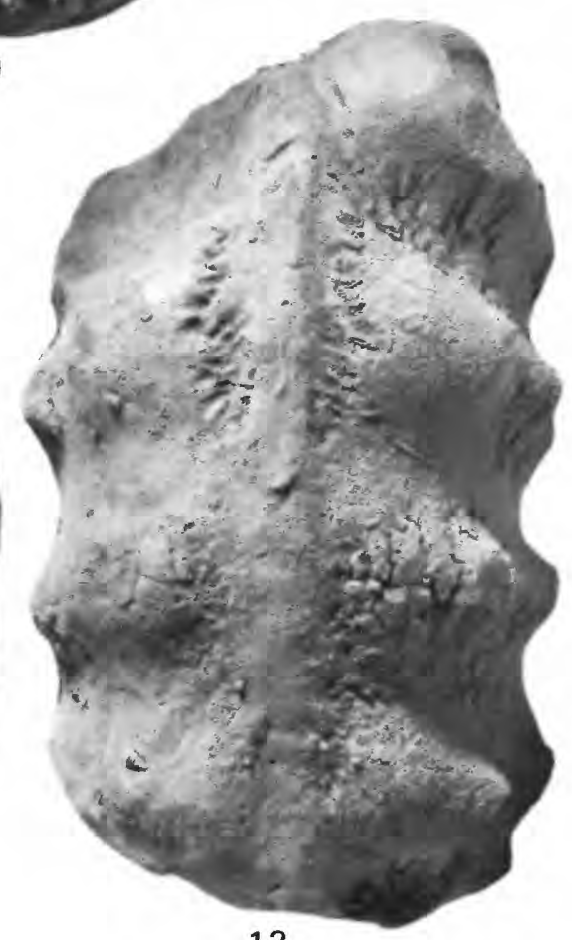

12
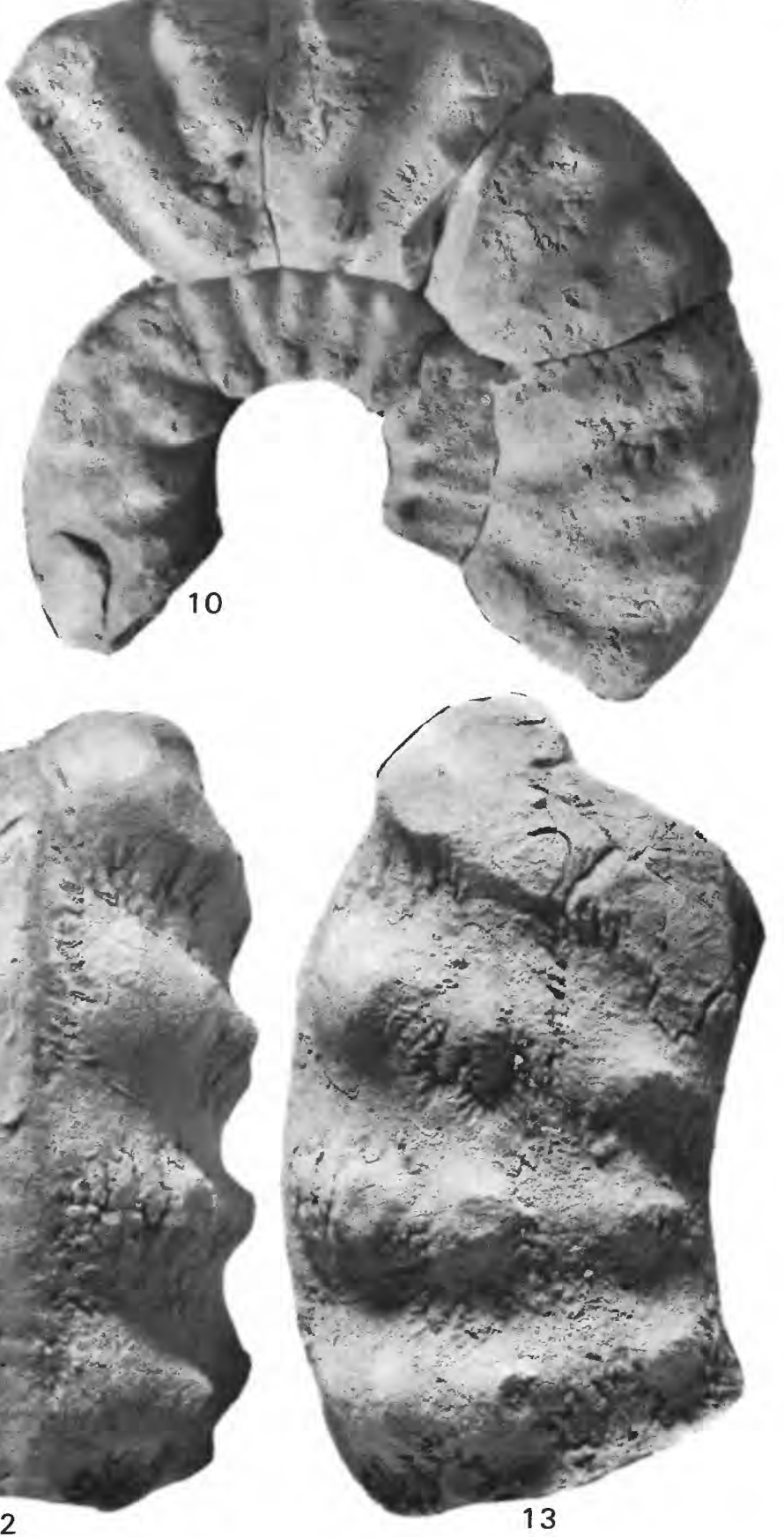

MORTONICERAS AND EOPACHYDISCUS 


\section{PLATE 4}

[All figures natural size. Localities shown on figure 1 in text]

Figures 1-10. Mantelliceras sp. (p. 9).

From USGS Mesozoic locality D10104.

1, 2. Figured specimen USNM 363035.

3, 4. Figured specimen USNM 363036.

5, 8-10. Figured specimen USNM 363037.

6, 7. Figured specimen USNM 363038.

11, 12. Engonoceras sp. (p. 10).

Figured specimen USNM 363054, from USGS Mesozoic locality D6830.

13. Mortoniceras (Drakeoceras) sp. (p. 9).

Figured specimen USNM 363051, from USGS Mesozoic locality D6833.

14, 15. Mortoniceras sp. (p. 8).

Figured specimen USNM 363045, from USGS Mesozoic locality D6830. 


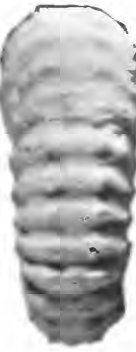

1
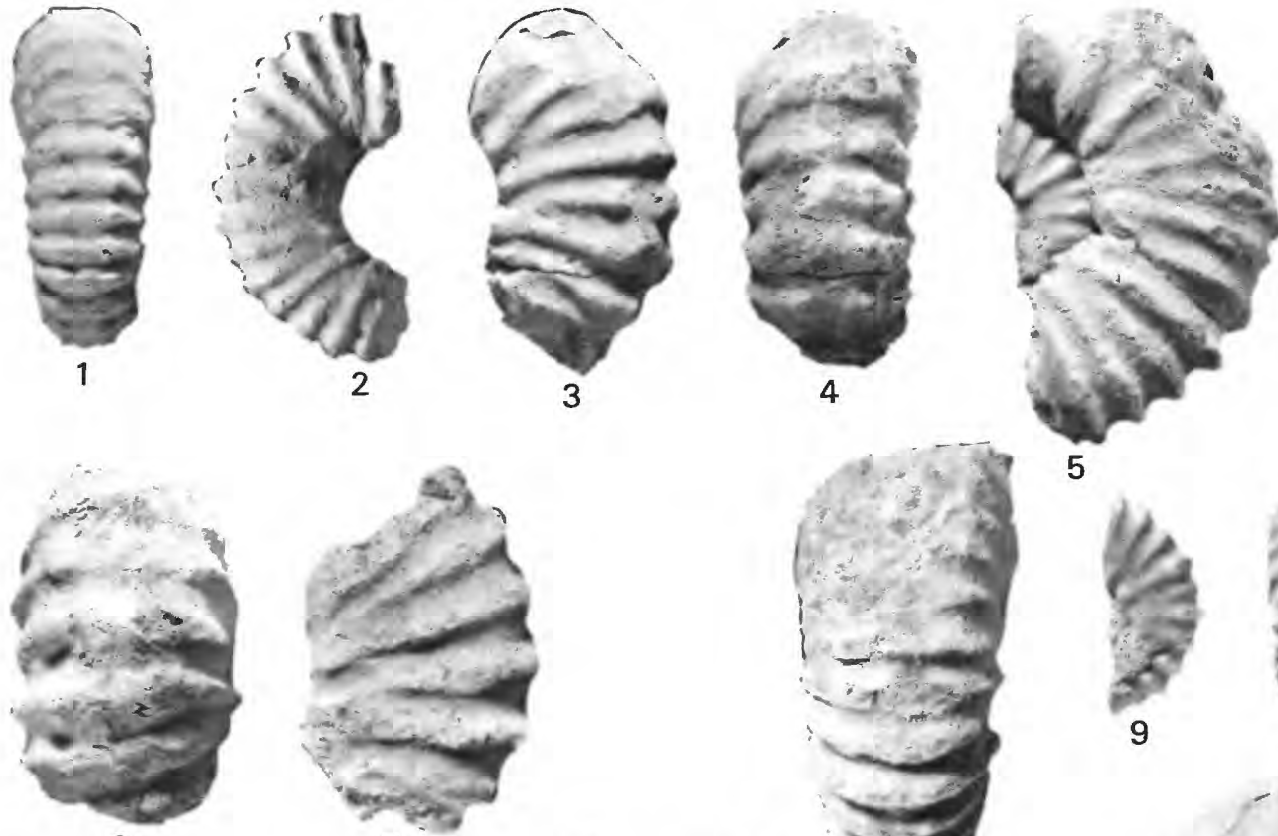

6
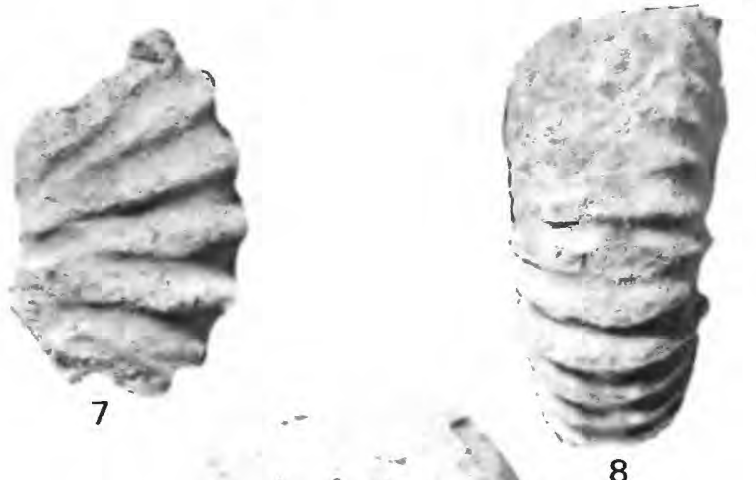

5
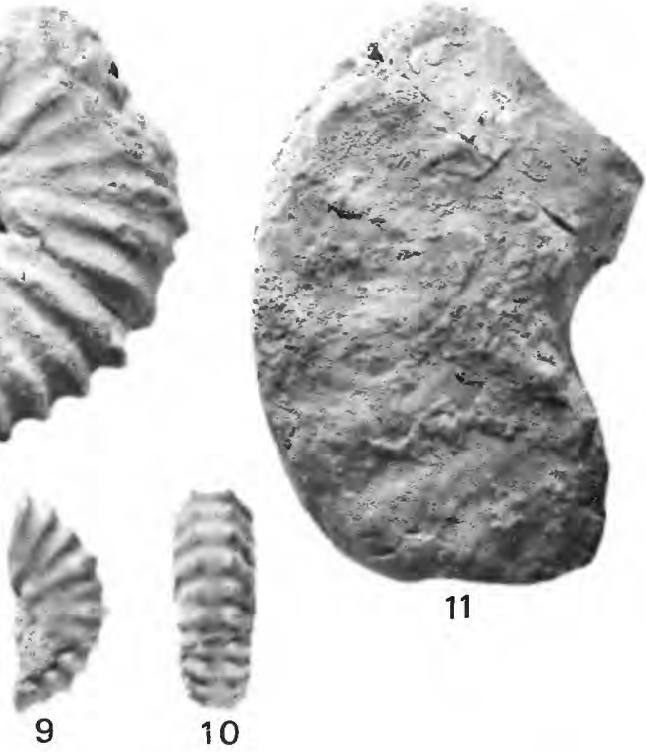

11

8

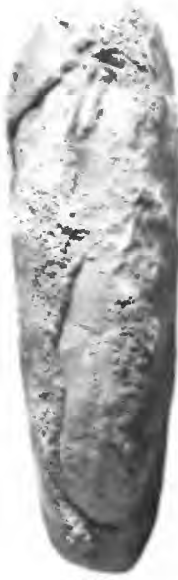

12

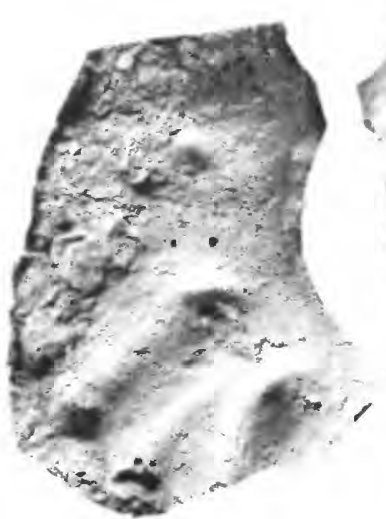

13
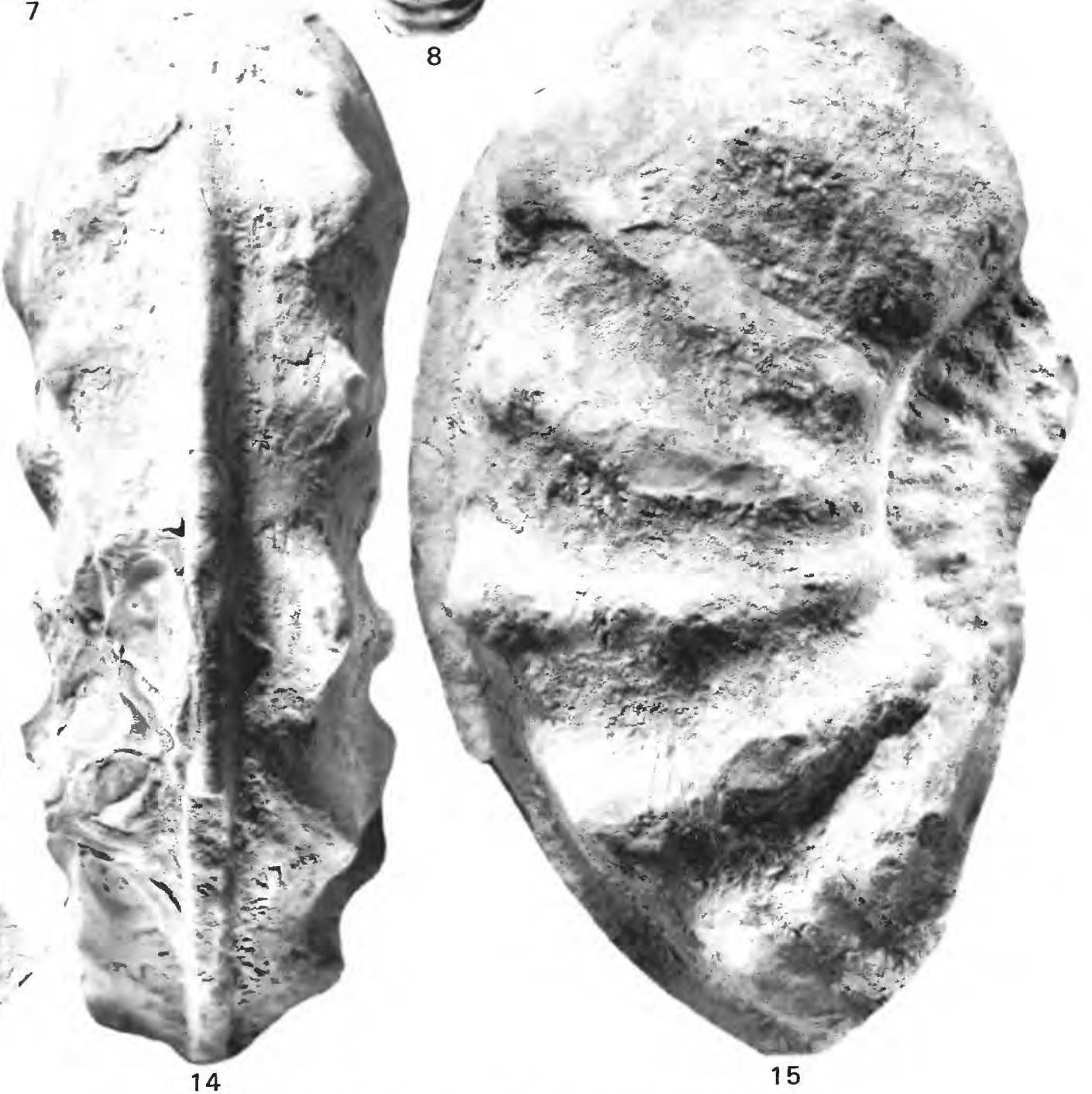

MANTELLICERAS, ENGONOCERAS, AND MORTONICERAS 


\section{PLATE 5}

[All figures natural size. Locality shown on figure 1 in text]

Figures 1-8. Mortoniceras equidistans (Cragin) (p. 6).

From USGS Mesozoic locality D6830.

1-3. Hypotype USNM 363042.

4, 5. Hypotype USNM 363043.

6, 7. Hypotype USNM 363044.

8. Hypotype USNM 363039. See plate 1, figure 8 , for side view. 

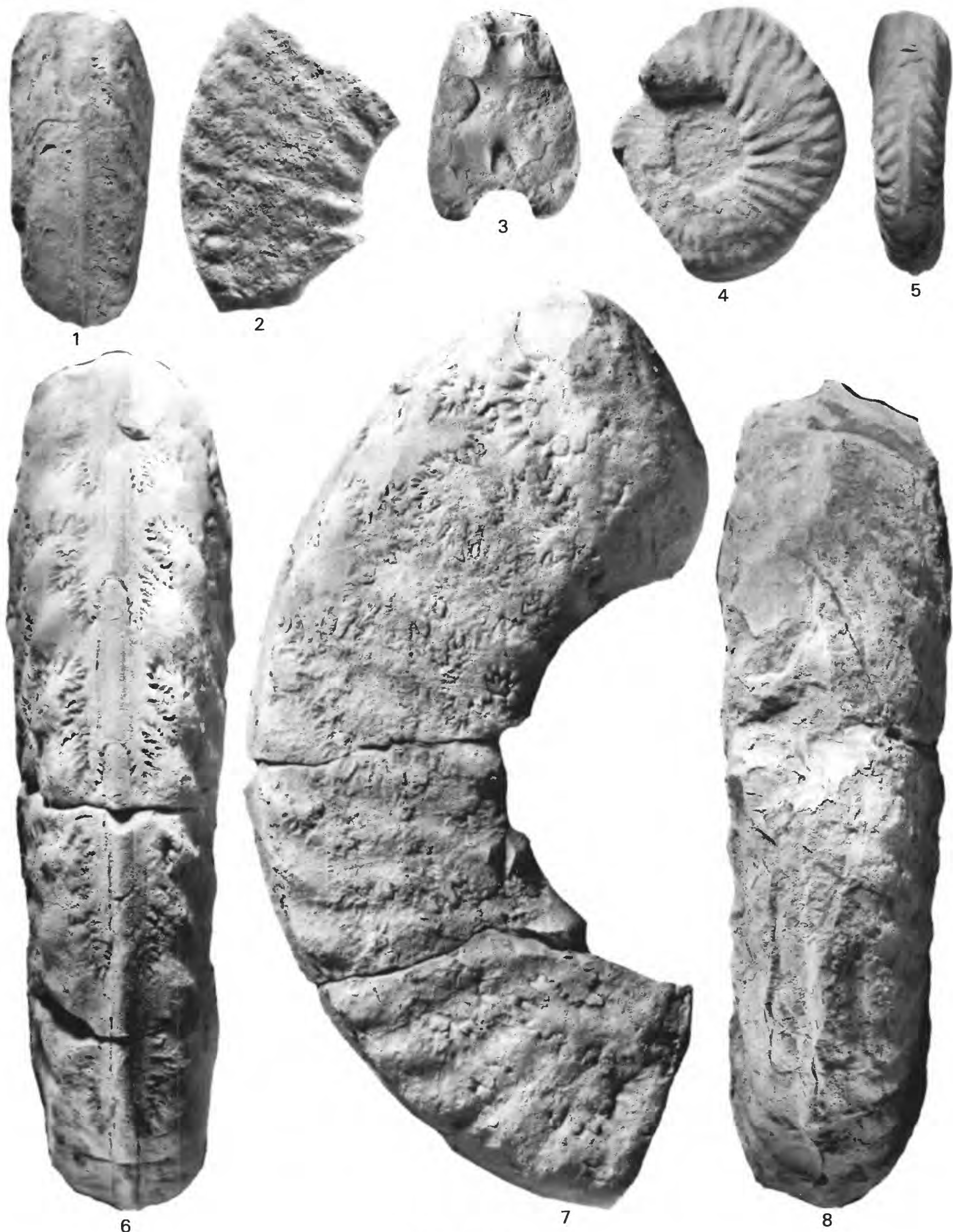

4
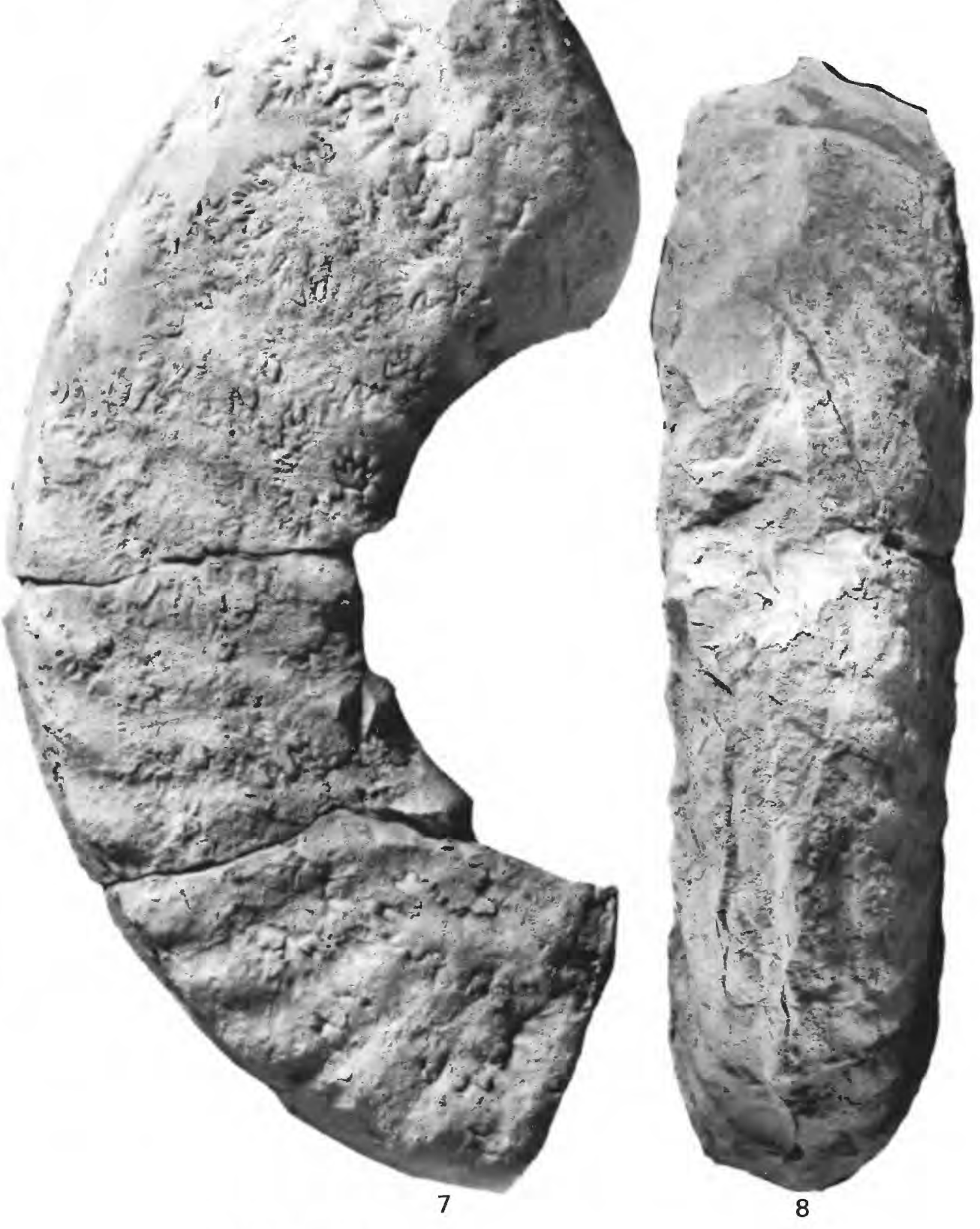


